\title{
A\\100 993732
}

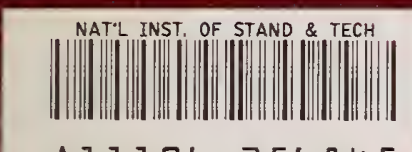

Al1106 256845 



The National Bureau of Standards' was established by an act of Congress March 3, 1901. The Bureau's overall goal is to strengthen and advance the Nation's science and technology and facilitate their effective application for public benefit. To this end, the Bureau conducts research and provides: (1) a basis for the Nation's physical measurement system, (2) scientific and technological services for industry and government, (3) a technical basis for equity in trade, and (4) technical services to promote public safety. The Bureau's technical work is performed by the National Measurement Laboratory, the National Engineering Laboratory, and the Institute for Computer Sciences and Technology.

THE NATIONAL MEASUREMENT LABORATORY provides the national system of physical and chemical and materials measurement; coordinates the system with measurement systems of other nations and furnishes essential services leading to accurate and uniform physical and chemical measurement throughout the Nation's scientific community, industry, and commerce; conducts materials research leading to improved methods of measurement, standards, and data on the properties of materials needed by industry, commerce, educational institutions, and Government; provides advisory and research services to other Government Agencies; develops, produces, and distributes Standard Reference Materials; and provides calibration services. The Laboratory consists of the following centers:

Absolute Physical Quantities ${ }^{2}$ - Radiation Research - Thermodynamics and Molecular Science - Analytical Chemistry - Materials Science.

THE NATIONAL ENGINEERING LABORATORY provides technology and technical services to users in the public and private sectors to address national needs and to solve national problems in the public interest; conducts research in engineering and applied science in support of objectives in these efforts; builds and maintains competence in the necessary disciplines required to carry out this research and technical service; develops engineering data and measurement capabilities; provides engineering measurement traceability services; develops test methods and proposes engineering standards and code changes; develops and proposes new engineering practices; and develops and improves mechanisms to transfer results of its research to the utlimate user. The Laboratory consists of the following centers:

Applied Mathematics - Electronics and Electrical Engineering ${ }^{2}$ - Mechanical

Engineering and Process Technology ${ }^{2}$ - Building Technology - Fire Research -

Consumer Product Technology - Field Methods.

THE INSTITUTE FOR COMPUTER SCIENCES AND TECHNOLOGY conducts research and provides scientific and technical services to aid Federal Agencies in the selection, acquisition, application, and use of computer technology to improve effectiveness and economy in Government operations in accordance with Public Law 89-306 (40 U.S.C. 759), relevant Executive Orders, and other directives; carries out this mission by managing the Federal Information Processing Standards Program, developing Federal ADP standards guidelines, and managing Federal participation in ADP voluntary standardization activities; provides scientific and technological advisory services and assistance to Federal Agencies; and provides the technical foundation for computer-related policies of the Federal Government. The Institute consists of the following divisions:

Systems and Software - Computer Systems Engineering - Information Technology.

'Headquarters and Laboratories at Gaithersburg, Maryland, unless otherwise noted; mailing address Washington,D.C. 20234.

${ }^{2}$ Some divisions within the center are located at Boulder, Colorado, 80303.

The National Bureau of Standards was reorganized, effective April 9, 1978. 


\section{International Trends and Developments of Importance to the Metrication Plans of the U.S. Construction Community}

JUN 211978

Charles T. Mahaffey

Building Economics and Regulatory Technology Division

Center for Building Technology

National Engineering Laboratory

National Bureau of Standards

Washington, D.C. 20234

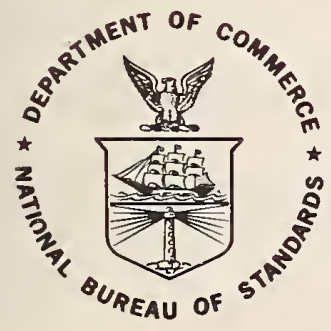

U.S. DEPARTMENT OF COMMERCE, Juanita M. Kreps, Secretary

Dr. Sidney Harman, Under Secretary

Jordan J. Baruch, Assistant Secretary for Science and Technology

NATIONAL BUREAU OF STANDARDS, Ernest Ambler, Director

Issued June 1978 


\section{Library of Congress Catalog Card Number: 78-600046}

\section{National Bureau of Standards Technical Note 976}

Nat. Bur. Stand. (U.S.), Tech. Note 976, 72 pages (June 1978)

CODEN: NBSMA6

For sale by the Superintendent of Documents, U.S. Government Printing Office, Washington, D.C. 20402 


\section{$\underline{\text { Page }}$}

SSTRACT. . . . . . . . . . . . . . . . . . . . . . . . iv

INTRODUCTION. . . . . . . . . . . . . . . . . . . . . . 1

THE HELSINKI AGREEMENT. . . . . . . . . . . . . . . . . . 3

THE PROPOSED GATT STANDARDS CODE. . . . . . . . . . . . . . . . . 4

IMPACT OF DIMENSIONAL COORDINATION. . . . . . . . . . . . . 6

ACTIVITIES WITHIN THE UNITED NATIONS. . . . . . . . . . . . . 7

5.1 Development of the UN/ECE Building Regulatory Harmonization Project. 8

5.2 JN/ECE Work Program Outline. . . . . . . . . . . . . . . . 10

5.3 UN/ECE Program for Quality Approval and Control. . . . . . . . . 12

EUROPEAN UNION FOR AGREMENT (UEA) . . . . . . . . . . . . . . . . 13

THE INTERNATIONAL ORGANIZATION FOR STANDARDIZATION - ISO. . . . . . . . 17

7.1 ISO-UN/ECE Working Arrangements. . . . . . . . . . . . . . . . . 19

7.2 Statement of ISO Policy in the Field of Building . . . . . . . . . . 21

7.3 Three Levels of International Standards. . . . . . . . . . . . . . 22

7.4 Broadened TD 3 Membership Base . . . . . . . . . . . . . . 23

7.5 TD 3 and the Technical Coordination Problems . . . . . . . . 23

7.6 ISO/TD 3 Divisional Council. . . . . . . . . . . . . . 24

7.7 Technical Committee (TC) 59 - Building Construction. . . . . . . 26

EXISTING U.S. RELATIONSHIPS WITH ISO AND THE UN/ECE . . . . . . . . . . 29

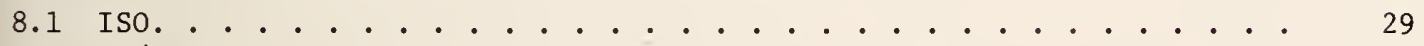

$8.2 \mathrm{UN} / \mathrm{ECE}$. . . . . . . . . . . . . . . . . . . . 30

A MAJOR METRICATION PLANNING AND REGULATORY ISSUE FOR THE U.S.

CONSTRUCTION COMMUNITY. . . . . . . . . . . . . . . . . . 31 PENDICES

Policy Statement $(\mathrm{UN} / \mathrm{ECE})$. . . . . . . . . . . . . . . 33

Prominent International Organizations Related to the UN/ECE-ISO

Harmonization of Building Regulations Project . . . . . . . . . . . . 40 
In 1974 the National Bureau of Standards' Center for Building Technology began an investigation of international developments in the construction field seeking to identify those of importance to U.S. metrication planning. This report identifies and describes a group of related developments selected on the basis of their importance and potential impact on the metric future of the U.S. construction community. The purpose of the report is not to discuss the merits of going metric, but rather to display the trends and developments in the metric building world that the U.S. is preparing to join.

The report suggests that many nations, recognizing unique opportunities in a world that will soon have a common measurement system, have already begun to capitalize on the global adoption of SI--the International System of Units. The report describes the extensive efforts underway to reduce obstacles to trade caused by incompatible national regulations, standards, and certification to standards. It describes the trade implications of the Helsinki international agreements reached at the Helsinki meeting of the Conference on Security and Cooperation in Europe and being advanced in the proposed Standards Code developed by the negotiators involved in the General Agreement on Tariffs and Trade (GATT). It describes the changes in the marketplace for building components brought about by the worldwide adoption of the international standard dimensioning module of $100 \mathrm{~mm}$. It describe the launching and the status of the United Nations project aimed at the international harmonization of national building regulations; the involvement and reorganization of the building standards activity of the International Organization for Standardization (ISO); the significance of the international evaluation mechanisms developed by the European Union of Agrément; and, the initiation of international performance standards developed through ISO Technical Committee 59 - Building Construction. All of these should be of speci interest to those concerned with the development of a remarkably similar program assigned to the National Institute of Building Sciences (NIBS).

U.S. metric conversion plans could be designed to take advantage of the opportunities uniquely associated with an SI world or they could treat metrication simply as the adoption of a more modern U.S. measurement system. The report identifies this choice as a major metrication issue for the U.S. construction community. For this reason, the report should be of interest to members of the American National Metric Council and of the U.S. Metric Board.

The appendix to this report contains a brief description of 22 international organizations considered to be of future significance to the U.S. as it joins the SI metric building wor 1 d.

Key Words: International building performance standards; internationally harmonized building regulations; metrication impact of construction 


\section{INTRODUCTION}

At the present time, prior to the formal start-up of the metrication program for the United States' construction industry, there is an opportunity to review current happenings and trends gathering momentum in the metric building world that the U.S. is preparing to join.. It seems that the more important of these developments are centered around international activities aimed at improvements in international trade. These activities stem from the change to the SI (Systeme International d'Unites) metric system that is a worldwide process. It is not just the U.S. and the other English speaking countries who are involved. Many of the nations who long have been on the metric system are using an older system which is now outdated by SI--the most modern measurement system in existence. They too are committed to the change to SI. Other English speaking countries-- the United Kingdom, South Africa, Australia, New Zealand, and Canada--are well into their conversion to SI. By the time the U.S. completes its metrication program the whole world will have, for the first time in history, an opportunity to employ a common measurement language. SI, the alphabet of this language, is making possible a new era for the world of standards, the technical, commercial and legal communication base in the exchange of goods and services at both the national and international level.

The growing concern regarding the U.S. share in world exports is reflected in a June 1974 report, "Voluntary Industrial Standards in the United States," prepared by the Library of Congress, Congressional Research Service, for the House Subcommittee on Science, Research and Development 19 which notes that:
"Over the last 15 years for which data is available, the total world trade, measured by the value of exports of all countries, tripled from \$103 billion in 1956 to $\$ 312$ billion in 1970. During the same period the U.S. exports increased from \$19 billion in 1956 to $\$ 43$ billion in 1970, indicating a slower growth than for the world as a whole. Over this 15 years, the U.S. share of the world market dropped from about 19 percent to about 14 percent, a decrease that is of concern to some observers."

Even under the present handicap of our inch/pound system, the U.S. construction industry accounted for approximately $\$ 2$ billion in exports in building products in 1975 . During the same period Engineering News Record (April 15, 1976) reported that 91 of the top 400 contractors in the U.S. accounted for $\$ 21.8$ billion in foreign construction contracts. This was 86 percent greater than in 1974 and six times greater than in 1972. This means that one out of every three dollars in total construction contracts awarded to the top $400 \mathrm{U} . \mathrm{S}$. constructors during 1975 was for work outside of the U.S. This American know-how has not usually been included in discussions of foreign trade, yet it is as exportable an item as any other important industrial product. As American manufacturers begin to plan the production of products in metric dimensions, they may find it beneficial to consider the new export opportunities in these American designed construction projects.

However, for a major segment of the U.S. construction materials producers, the subject of international trade may not seem too relevant at this time. But, since many building products will actually undergo a physical size change during metrication, some alert industry members will consider international trade opportunities in designing their new line of metric products. This consideration may reveal unexpected opportunities associated with discernible worldwide trends that might be exploited, especially during the conversion to SI.

In this report, particular attention is paid to those trends considered to be establishing a better climate for international trade and that are, thereby, exerting a strong "changecourse" influence over the whole field of building, building products, and related building standards and regulations in the new, evolving metric building world.

1/Superintendent of Documents, U.S. Government Printing Office, Washington, D.C. 20402. 
The interesting importance of these international, trade-oriented developments is that they are just as applicable at the national level. The point being that those who cooperatively participate in these international activities for the purpose of capitalizing on the long term international trade aspects may find the results of this participation also useful in national applications, while enjoying the reduced development costs of a collaborative internationa1 approach.

The major influences of this nature covered in this report are:

- The Helsinki Agreement

-- The Conference on the Security and Cooperation in Europe held in Helsinki in 1975. The Presidential-level Conference of 35 nations pledged governmental support for the elimination of technical obstacles to international trade caused by standards and technical regulations.

o The proposed GATT Standards Code

-- The multinational negotiators in the General Agreement on Tariffs and Trade (GATT) are proposing an international methodology for reducing the technical obstacles to trade caused by national standards, certification to standards and technical regulations.

o Dimensional coordination in the metric building world

-- The global adoption of coordinated, preferred metric dimensions for buildings and their component parts, based on the international module of $100 \mathrm{~mm}$, is creating entirely new marketing opportunities for building products, systems, and designs throughout the world.

o The harmonization of building regulations project of the United Nations Economic Commission for Europe (UN/ECE)

-- This 34 nation (including the U.S. and Canada) program is specifically directed towards the elimination of obstacles to international building trade through the application of the performance concept to national building regulations.

o The European Union of Agrement

-- The nine nation consortium of national institutions engaged in the performance evaluation of innovative building products and systems.

o The emerging international building standards development program of the International Organization for Standardization (ISO)

-- With a mandate from the governmental bodies in the UN/ECE, ISO is preparing to launch a coordinated, performance-based building standards development program.

In addition to these ongoing activities, the report also discusses current U.S. relationships with both the UN/ECE and the ISO. It also highlights some of the issues presented to the U.S. building community by these international activities, especially as they relate to the new National Institute of Building Sciences (NIBS). It is intended as an up-to-date collection of information gathered from the author's participation in almost 30 formal (and twice the number of informal) international meetings from mid-1974 through 1977. The information presented is an attempt at an objective interpretation of the trends exhibited by the events and related activities witnessed in the emerging metric building world. 
The purpose of this report is to display these activities as an aid to the members of the U.S. building community who, as a result of metrication, will soon be involved in making decisions that are bound to affect the economic health of the U.S. construction community for a long time to come. These decisions, their nature and timing, are management decisions. American management, both in the public and private sectors, should be aware of the thrust, status and potential impact of these international developments, especially as they affect national building standards and technical regulations. These two subject areas have been especially singled out for corrective attention by the heads of the 35 nations involved in the 1975 Conference on Security and Cooperation in Europe. Because this Conference was held in Helsinki, it is popularly referred to as the Helsinki Agreement.

\section{THE HELSINKI AGREEMENT}

Reflecting the belief that many new opportunities must now exist to exploit the improved communicability inherent in a common, worldwide measurement base, many nations have begun to seriously examine their long-established practices in international trade. Since one of the most useful applications of any measurement language is in the field of standards and technical regulations and since both are involved, in a basic manner, in international trade, both are coming under an ever closer international scrutiny. An example of the seriousness of this international scrutiny can be seen in the attention given this subject area by the leaders of 35 nations involved in the 1975 Conference on Security and Cooperation in Europe held in Helsinki. Former President Ford was one of the signatories to the agreements adopted at this Conference. Differing U.S. viewpoints regarding the value of some of these agreements, as reported in the media, are usually concerned with whether we or the Soviets "won" at Helsinki, and usually in the political and social areas (such as human rights). Emphasis on these features of the Conference have tended to obscure the significant agreements reached in the economic area. An example of the latter is seen in the Final Act of the Conference which contains the following passage:

\section{"The participating States,}

Recognizing the development of international harmonization of standards and technical regulations and of international cooperation in the field of certification as an important means of eliminating technical obstacles to international trade and industrial cooperation, thereby facilitating their development and increasing productivity, reaffirm their interest to achieve the widest possible international harmonization of standards and technical regulations: express their readiness to promote international agreements and other appropriate arrangements on acceptance of certificates of conformity with standards and technical regulations: consider it desirable to increase international cooperation on standardization, in particular by supporting the activities of intergovernmental and other appropriate organizations in this field."

The thrust of this passage is in the direction of greater economic cooperation, a theme attracting wider attention as recurring national shortages and surpluses suggest the need and opportunities for better modes of international trade. John Landis, President of the American National Standards Instityte (ANSI), speaking to the American National Metric Council (ANMC) on March 19, 1975, $\underline{2}$ said:

"Economic integration is the goal of the European Common Market, and when that integration process is complete, Europe will virtually equal the U.S. in market potential. It is likely, moreover, that integration will not stop with Europe; the momentum of metric conversion may well carry the non $\overline{3}$ Furopean industrialized countries and the developing countries along with it."

2/"Metric Implementation and the Role of Standards," John W. Landis, American National Standards Institute, 1430 Broadway, New York, New York 10018.

$3 /$ For more information on European Common Market operations, see the description of the EEC-European Economic Community in the Appendix, page 46. 
"These changes on the world scene have taken place at a time when unemployment at home and balance of payments problems abroad have made it clear that the United States cannot afford to stand alone in an economically integrated world."

Thus, the global field of standards and technical regulations, identified in the Helsinki Agreement, is becoming a focal point of attention as a result of the worldwide adoption of SI. It is well to note that the change to SI requires an indepth examination of all existing standards and regulations. In many cases, this kind of a conversion examination provides opportunities for major revisions. Not only must the U.S. and all of the converting English-speaking countries go through this examination and rewriting process, but so do many of the other nations who have long been on older, pre-SI metric systems. Thus, the Helsinki Agreement supports the concept and thrust to "harmonize" standards resulting from the revision opportunities presented by thw worldwide change to SI. It comes at a particularly opportune time for the U.S. which is just beginning its conversion--revision process. Sometimes it is advantageous to be last, for our standard's developers now are being offered a unique opportunity to include consideration of these international trends in the management decisions that must be made relative to our metrication planning obejctives.

\section{THE PROPOSED GATT STANDARDS CODE}

Another example of this international trend is the current activity going on in the Multilateral Trade Negotiations (MTN) in Geneva. Some eighty nations, including the United States, are involved in the MTN, a working group whose goal is to achieve as liberal a basis for trade as practical. Reduction in tariff as well as non-tariff barriers are being negotiated. The objective of this forum is to achieve agreement that maximize trading opportunities and minimize difficulties for domestic industries of the participating nations. The MTN operates under the auspices of the General Agreement on Tariffs and Trade (GATT). Since the beginning of the GATT in 1947, seven such rounds of negotiations have occurred with the current session, called the Tokyo Round, having begun in 1973. An important issue in the Tokyo Round is a standards code for products traded internationally.

This proposed GATT Standards $\operatorname{Code}^{4 /}$ seeks to establish international rules concerning the procedures by which national standards are to be prepared, adopted, and applied, to ensure that they do not become barriers to international trade. It was the recognition of the trade problems posed by national and regional differences in standards, and the inadequacy of the GATT provisions to deal with them, that has led the contracting parties to develop a Code of Conduct for Preventing Technical Barriers to Trade (a standards codes).

Briefly, this proposed GATT Standards Code will specify certain procedural rules for adherents to follow in adopting standards, test methods, technical regulations, and certification systems for products which are or could be traded internationally. These procedural rules are designed to:

- eliminate the use of standards as a means of discriminating (either intentionally or unintentionally) against imported products;

- promote the development, adoption, and use of international standards, when appropriate; and,

4/ Copies of an abstract of this document can be obtained from the office of the Special Representative for Trade Negotiations, Executive Office of the President, Washington, D.C. 20506. 
- promote the use of open, consensus-type procedures in developing all product standards.

The proposed Code strongly recommends the application of the performance concept, especially in the writing of technical regulations involving products that are or could be traded internationa11y.

As might be expected, the international scope of the proposed Code results in procedures that are complicated and that pose difficult compliance problems, especially for countries utilizing a Federal system of government (such as the U.S.) where regulatory authority is not centralized. The proposed Code takes special note of this problem and pointedly requires the central government (the signatory) to "use all reasonable means within their power" to ensure that regulatory bodies other than the central government also adhere to the provisions of the Code. Since this applies to standards, regulations, and all systems of certification to standards and regulations, the problems for the U.S. are very 1 arge.

Drafters of the code evidently have found that if the substitution of international standards for possibly incompatible national standards could be effected, this latter form of trade barrier could be eliminated most simply and most effectively. The draft contains numerous passages to this effect such as:

"Where standards are required and relevant international standards exist or their completion is imminent, adherents shall use all reasonable means within their power to ensure that these standards or the relevant parts of them are used as the basis for the standards..."

The proposed Standards Code also addresses the related international problems connected with the cost and delay of multiple testing which is usually required in certifying compliance with applicable standards. This is proposed to be carried out through a means of recognizing the validity of certification systems operative in the originating country.

In a background paper $5 /$ on the proposed Code, Mr. Frank LaQue states:

"It can be expected, therefore, that adoption of a GATT Code would stimulate and require a greatly expanded and accelerated effort to provide international product standards suitable in form and content for use in technical regulations. It follows, also, that protection of U.S.A. interests would require a correspondingly high level of U.S.A. participation in international standardization."

There is good reason to believe that the GATT negotiators were spurred in the production of this proposed Standards Code by an understanding of the impact of the worldwide movement to SI. While the problem this code addresses existed before the worldwide metrication movement became certain, that certainty removes a basic technical barrier and greatly improves the chances of finding a workable solution. The solution now proposed is cumbersome. However, it could be made to work with a great amount of diligent effort. The fact that so many nations are even considering the voluntary adoption and use of these complicated GATT procedures, in order to open the doors to international trade, is perhaps indicative of the strength of this movement. It is the strength and persistence of this striving for better international trade mechanisms, represented by both the Helsinki Agreement and the GATT Standards code, that warrants serious consideration by a metricating United States.

5/ANSI Seminar, GATT Standards Code, January 17, 1977, F. L. LaQue. Published by American National Standards Institute, 1430 Broadway, New York, New York 10018. Mr. LaQue is a former Vice President of International Nickel Co., a Past President of the American National Standards Institute and of the International Organization for Standardization. 


\section{IMPACT OF DIMENSIONAL COORDINATION}

For U.S. building product manufacturers there is a special trade opportunity developing as a result of metrication other than the fact that the product and its descriptive literature will be in metric terms. This has to do with the worldwide movement within the industry towards coordinated metric dimensions for buildings and building products. This move is centered around the global adoption and use of standards describing a dimensioning methodology based on preferred multiples (and submultiples) of $100 \mathrm{~mm}$ (3.937 inches), the internationally accepted coordination module. The series of standards describing this methodology has been produced by the International Organization for Standardization (ISO) 6 . Under guidance provided by these standards:

o Designers can select internationally preferred multiples of $100 \mathrm{~mm}$ in establishing the principal dimensions of buildings and in locating components.

o Builders can more easily lay out the erection stages of construction, eliminating most of the usual site cutting and fitting.

- Component manufacturers can concentrate production runs in selected series of preferred sizes relatable to preferred design dimensions.

Where metrication seems to require a "hard" conversion--the selection of new and significantl different component sizes, manufacturers of a presently successful line of such products are understandably hesitant about making such changes. The widespread acceptance of the principl of dimensional coordination and its application to buildings and components, governed largely by existing ISO standards, tends to reduce the risk involved. Mr. Dean Swift, President, Sears, Roebuck and Company, speaking to industry generally at the 1977 American National Metric Council (ANMC) Annual Convention, said:

"One of the highest priorities we see is the need for international metric standards. When it comes to hard conversion, going metric is decidedly risky for companies until there is acceptance of international standards for all their products. In many segments of industry, this design of metric products is still awaiting the emergence of those standards."

For the metricating U.S. construction industry the existence and global adoption of ISO dimensional coordination standards represents an important ongoing activity that is producing a marketing situation worthy of serious consideration.

Almost all of the industrialized nations have been increasing their use of $100 \mathrm{mrn}$ for the sizing of buildings and building products. When the construction industry in the United Kingdom started its metrication program, dimensional coordination became its central theme. As a result, many United Kingdom product manufacturers discovered unexpected cost benefits associated with making actual physical size changes in their products in the process of converting to. new metric dimensions. They found that through the use of $100 \mathrm{~mm}$ and selected multiples they could rationally select a more versatile range of new product sizes which:

o simplified the inventory problems of their distributors;

o were easier to design into buildings; and

o reduced the wasteful cutting and fitting normally associated with the on-site assembly of uncoordinated products.

6/Copies of these Standards may be obtained from the American National Standards Institute, 1430 Broadway, New York, New York 10018.

7/Copies of Mr. Swift's talk may be obtained from the American National Metric Council, 1625 Massachusetts Avenue, NW., Washington, D.C. 20036. 
These manufacturers were helped by the actions of the public construction agencies in the United Kingdom who placed the full weight of their design and purchasing strength behind these industry decisions, encouraging and easing a uniform adoption of the $100 \mathrm{~mm}$ sizing module.

Australia and Canada, after carefully reviewing the United Kingdom metric/dimensional coordination experience, were able to streamline their programs, further expanding the worldwide use of $100 \mathrm{~mm}$ as the basic sizing module. From present indications, it appears that the U.S. will also make use of coordinated, preferred metric dimensions using the same international module. For the worldwide construction community this means that not only will all members be using the same metric base but the majority of the new metric products will be internationally compatible dimensionally. Each successive adoption of these international standards by the United Kingdom, South Africa, Australia, New Zealand and Canada has significantly widened the already large market for size-coordinated products and systems. The adoption of similar preferred metric dimensioning practices by the U.S. could more than double the marketing range for many U.S. products. This developing worldwide market for building products will mean that many U.S. manufacturers, for the first time, will be able to consider seriously extending the marketing range of their products into the international marketplace.

Thus a clearly discernible trend towards a greatly improved climate for international trade in building products and know-how is shown by:

(a) the Helsinki Agreement

(b) the proposed GATT Standards Code

(c) the widespread international use of the $100 \mathrm{~mm}$ sizing module

These factors are worthy of serious consideration by the American construction community as it begins to plan the metric conversion of its entire building standards data base.

\section{ACTIVITIES WITHIN THE UNITED NATIONS}

Another very important international activity, one that is pointed specifically at the construction community, is the harmonization of building regulations program underway in the United Nations' Economic Commission for Europe (UN/ECE). Like the thrust of the quoted portion of the Helsinki Agreement and the whole of the proposed GATT Standards Code, this UN/ECE project is aimed at cooperatively removing obstacles to trade. In this instance, it is aimed directly at the trade barriers caused by national building standards and national, prescriptive-type building regulations now in use among the 34 member governments within the UN/ECE/. The central theme of this project is a greatly expanded use of international building standards and the development and use of an internationally standardized methodology for: (a) rewriting national building regulations in functional or performance terms, and (b) accepting product or system evaluations made at the national level. The term "harmonization" is used in recognition of the fact that because of social, political, and economic differences among the participating countries, it probably would not be possible to obtain uniformity of required performance levels. However, it is believed that if performance-based regulations could be uniformly presented, using a uniform terminology and format, and making use of uniform, internationally standardized test methods, national differences in acceptable performance levels could be tolerated. Such differences would be considered "harmonized" by reason of the similarity in their performance requirement statements and the uniformity of their evaluation procedures. The intent here is not to do away with traditional national construction techniques and products, but rather to permit them to co-exist and compete in an ever-widening selection of acceptable solutions to national performance-based requirements.

8/The UN/ECE should be distinguished from the EEC (the European Economic Community). The EEC is a regional organization including nine Western European countries banded together in what is popularly known as the Common Market. The UN/ECE is composed of all Eastern, Western and Southern European countries, the Nordic countries, plus Great Britain and Ireland. The United States and Canada are also members of the UN/ECE and have been voting members since World War II. 
The international harmonization work of the UN/ECE in this subject area is intended to be carried out through the cooperative efforts of the institutions within the UN/ECE countries that draw up and/or issue the technical requirements involved. The plan envisions that the central government in each of the participating countries will designate the institution within that country that is to be responsible for making the action-commitments, both at the national and international level, required by this voluntary, cooperative, international project. The institution appointed is expected to be the promulgator of either the national building regulations themselves or of other national documents that have similar effects.

The U.S. Department of State has appointed the Department of Housing and Urban Development (HUD) as the U.S. representative. The NBS Center for Building Technology (NBS/CBT) has been serving as technical advisor to HUD in the UN/ECE project. The author of this report has been acting as the advisor and has been in attendance at several of these UN/ECE meetings, usually held at the Palace of Nations in Geneva, Switzerland.

\subsection{Development of the UN/ECE Project}

The reasoning behind the relatively recent (1973) initiation of this UN/ECE project aimed at harmonizing the technical content of building regulations can be traced to:

(a) the international adoption of the SI metric system and the international standards pertaining to dimensional coordination;

(b) a steady growth in the number of ECE countries having uniform nationwide building regulations; and

(c) the limited marketing potential and generally unsatisfactory results experienced in trying to negotiate the removal of obstacles to trade caused by national building regulations through such regional organizations as the European Common Market (EEC), the Nordic Comittee on Building Regulations (NKB) or the Soviet bloc countries in the Council for Mutual Economic Assistance (CMEA).

There is little doubt that the worldwide change to SI contributed to the initiation of this project. Without the underlying technical communication base of the SI measurement system, the chances of so ambitious a project ever succeeding would be very slim. This international measurement base, plus the widespread international adoption and use of the standards describing the principles of dimensional coordination, has generated an entirely new climate of confidence in the efficacy of international building standards.

Additionally, there has been a steady growth in the gumber of UN/ECE countries that have enacted nationwide building regulatory systems. - Thus, a cadre of regulatory authorities exists among these countries who are able to deal responsibly with problems of reconciling their regulations.

Industrial organizations, anxious to increase the marketing area for their products or construction systems, and hampered by the existence of dissimilar prescriptive-type national building regulatory systems, began to encourage these national authorities to consider reconciliation measures. Limited successes were achieved along these lines particularly by the four Nordic countries (Finland, Sweden, Denmark, and Norway), members of the regional organization known as the Nordic Committee on Building Regulations (NKB).

Early NKB attempts revealed the seemingly insurmountable problems involved. Compromises needed to effect reconciliations of prescriptive requirements based on national and traditional practices and materials tended to lead to least common denominator solutions which were acceptable to none. Persisting in their efforts, the negotiators involved were

9/Building regulations in ECE countries, 1974, United Nations ECE/HBP/7, Inited Nations, Palais de Nations, Geneva, Switzerland. 
led inexorably to consideration of rewriting their regulations in functional or performance terms. They were led to this conclusion because it became clear that the systems and materials used within each country represent acceptable but different solutions to very similar objectives. It was realized that if the objectives inherent in prescriptive-type requirements could be formulated properly, the number of acceptable solutions might be greatly increased, limited only by the ingenuity of the manufacturers/designers and/or the technological capabilities of the evaluators.

Convinced that it was fruitless to continue seeking reconciliations of existing prescriptivetype regulations, concerned individuals (mainly from the Nordic countries) pressed for the initiation of a large-scale international harmonization project. The mechanisms within the United Nations, particularly the Economic Commission for Europe, seemed ideal for this purpose, especially since the U.S. and Canada were voting members.

Guiding principles for the projected program were agreed upon by a committee called the Working Party on the Building Industry, a subgroup of the UN/ECE Committee on Housing, Building and Planning (HBP). The latter group endorsed the project in 1971 . Detailed proposals regarding the program were worked out at a first preparatory meeting held in Geneva in January 1972. The resulting seminar, known officially as the Fourth ECE Seminar on the Building Industry, was held in London in October 1973.

The central theme of this UN/ECE Fourth Seminar on the Building Industry was the harmonization of building regulations and standards to promote international trade. The meeting was attended by 29 nations and 12 international organizations and included 230 individual participants. The final Policy Statement worked out in London is so relevant to an understanding of the project and its significance for the U.S. that it is reproduced in its entirety in Appendix I. This Policy Statement is wide-ranging in its considerations and is probably the most comprehensive and detailed set of objectives ever enacted for the building community, especially by a UN/ECE group. It could and probably will serve as a guide to the efforts of all governmental bodies interested in this field for some decades to come.

This Policy Statement calls attention to:

(a) the importance of construction to the economy of each country;

(b) the need for greater productivity through industrialization;

(c) the need for large market areas to foster such industrialization;

(d) the obstacles to such expansion caused by national standards, certification to standards, and building regulations.

It proposes that member countries of the UN/ECE should:

(a) coordinate the establishment of technically coherent national standards and regulations;

(b) standardize the presentation of information on building products suitable for international trade;

(c) participate in the development and use of international standards describing the methodology to be used in writing regulations in functional or performance terms that would include the establishment of a recommended range of acceptance values;

(d) participate in the development and use of international standard test methods;

(e) participate in the development and use of an international system for accepting products or processes which are subjected to an appropriate foreign approval confirmed by a national body; 
(f) support research activities related to building standards and regulations;

(g) promote the rapid introduction of the use of SI in building standards and regulations;

(h) promote the uniform adoption and use of a fully developed system of dimensional coordination;

(i) participate in the development and use of such international standards that may be uniformly referenced in national building regulations.

\subsection{UN/ECE Work Program Outline}

Subsequent meetings of the UN/ECE Working Party generated a more specific four-part Work Program Outline describing those activities considered necessary for the successful harmonization of the technical content of building regulations:

Part 1: MEASURES INTENDED TO INSURE A MUTUAL EXCHANGE OF INFORMATION ON BUILDING REGULATIONS.

1.1: Report on systems of building regulations in ECE countries.

1.2: Directory of national information centers on building regulations.

1.3: Directory of national central approval agencies for buildings or components and for professional competencies.

1.4: Index of general national building regulations.

1.5: Illustrated catalogue of structural systems and building components generally approved at the national level and aimed for international trade.

1.6: Directory of unified building regulations and guidelines valid on June 1, 1974.

1.7: Study on trade and obstacles to trade in the field of building products and know-how.

Part 2: MEASURES INTENDED TO UNIFY THE PRINCIPLES FOR THE FORMULATION OF BUILDING REGULATIONS

2.1: Unified systems for writing building regulations in functional or performance terms.

2.2: Principles of making reference to standards and other documents in building regulations.

2.3: Multilingual glossary on building technology and building products.

2.4: Multilingual terminological dictionary.

Part 3: MEASURES INTENDED TO HARMONIZE PROCEDURAL REQUIREMENTS RELATING TO APPROVAL AND QUALITY CONTROL OF BUILDING COMPONENTS.

3.1: Rules for quality approval and quality control of building products aimed for international trade. 
Part 4: MEASURES INTENDED TO HARMONIZE THE TECHNICAL CONTENT OF BUILDING REGULATIONS.

4.1: Building climatology and geophysics. Basic principles for design.

4.2: Uniform principles for requirements on load-bearing structures, including design loads.

4.3: Fire protection requirements for buildings.

4.4: Uniform criteria for human requirements with regard to the internal climate of buildings.

4.5: Regulations for designing concrete structures.

4.6: Regulations for designing metal structures.

4.7: Regulations for designing timber structures.

4.8: Unified requirements on optinum measurements for dwellings (room heights, stair widths, door sizes, etc.).

4.9: Energy conservation in buildings.

The governmental bodies involved in this UN/ECE project recognize that the new performancebased, model regulatory system envisioned, though developed specifically for the purpose of improving international trade, also has great internal benefits for each country adopting a national system compatible with the international model. The regulatory simplification demands imposed by the concern for improvements in international trade should not only simplify national regulatory systems and increase their flexibility, but should actually decrease the very volume of the regulations themselves. The design and development of such a suitably simple system is considered possible, but difficult and expensive. This UN/ECE project, a cooperative venture, is designed as a cost-sharing activity that makes it economically attractive to all participants.

The governmental bodies involved have parceled out several portions of the Work Program Outline as a way of conserving both money and time. In the area of international standards, which is so crucial to the thrust of the whole project, the governmental bodies have practically offered the International Organization for Standardization (ISO) a partnership role in the project. This involves the key standards development work that will establish a uniform methodology for installing a performance-based regulatory system (2.1 in the Work Program Outline) and the broad-ranging standards in all of Part 4. A further elaboration on this standards area will be dealt with in a subsequent section of this report.

UN/ECE has also asked the CIB (International Council for Building Research, Studies and Documentation) 10 and RILEM (International Union of Testing and Research Laboratories for Materials and Structures) $10 /$ for special assistance. Both organizations have been asked to respond to the harmonization research needs of the governmental agencies involved and also to the research needs of ISO Technical Committees, particularly in the area of internationally standardized test methods.

The UN/ECE group has reached a tentative or working agreement relative to 2.2 in the Work Program Outline -- principles of making references to standards and other documents in building regulations. At an ad hoc meeting of experts held in Sofia, Bulgaria, in October of 1974 , it was agreed that:

$\underline{10 / C o n c i s e ~ d e s c r i p t i o n s ~ o f ~ b o t h ~ g r o u p s, ~ i n t e r n a t i o n a l ~ o r g a n i z a t i o n s ~ o f ~ n a t i o n a l ~ b u i l d i n g ~}$ research institutions, are given in Appendix II to this report. 
1. Applicable international standards (particularly test methods or climatological design data) should be referenced in national building regulations to the greatest practical extent.

2. National standards, other than test methods, could be referenced in national building regulations, provided the referencing is done in a "deemed-to-satisfy" manner so as not to impede the consideration of alternatives.

\subsection{UN/ECE Program For Quality Approval and Control}

While parceling out large portions of the standards developmental work to ISO and others, the UN/ECE group has apparently considered the following to be their particular developmental areas:

- The information gathering activities in Part 1 of the Work Program Outline.

- The glossaries and dictionaries in Parts 2.3 and 2.4.

- The very difficult problems connected with the international harmonization of existing (or planned) national quality approval and quality control systems.

The terms "quality approval" and "quality control" are used by the UN/ECE in the following context:

1. Quality Approval

The procedure of formal acceptance of a building product, component, assembly or construction system for use in building once it has been submitted to a regime of tests, assessments or checks successfully establishing compliance with stated requirements.

2. Quality Control

Systems of quality approval rely on control procedures for ensuring that approved products or systems actually used at the job site are the same as those submitted for prototype approval. These control procedures involve both site inspections and/or frequent inspection of production processes and the application of appropriate marks or labels identifying products manufactured under these control procedures.

Both of these activity areas often form an integral part of every national regulatory system. Developed originally for internal use, there are as many existing varieties of quality approval and quality control mechanisms as there are regulatory systems. Though they all have similar objectives, the procedures under which they operate differ widely. In many countries these procedures are part of the building regulations themselves and the latter often specify those national institutions that may be used for this purpose. The different evaluative methods used in these national arrangements make it extremely difficult to determine equivalent performance among existing products or systems, and strongly suggest the need to develop a new internationally harmonized evaluation mechanism centered around the use of national institutions accredited in the use of international test methods.

The importance of this quality approval/control subject area cannot be overemphasized. It was specifically identified as a major obstacle to trade in the Final Act of the 1975 Helsinki Agreement. It is identified as a major problem in the proposed GATT Standards Code and it is mentioned several times il/ in the UN/ECE Policy Statement adopted at the 1973 meeting in London.

11/See Sections E2, F3, F4, F5, F7, F8 and H2 of the Policy Statement. 
The governmental bodies in the UN/ECE called a special ad hoc meeting of experts in quality approval/control for June 1976 in Geneva. At this meeting the delegates came to the conclusion that the resolution of this subject area was central to the harmonization of the technical content of building regulations. So central, in fact, that several of the delegates expressed the opinion that if they could solve this problem area the harmonization of building regulations would become relatively easy.

Out of this June ad hoc meeting, two potentially fruitful lines of development became apparent:

1. International performance test method development needs to be steppedup dramatically.

2. The possibility of expanding the existing operational range of the European Union of Agrément (UEA) needs to be explored in some depth.

Delegates to the June 1976 meeting were unanimous in endorsing the need for internationally standardized test methods. Performance-based regulatory systems are always centered around a product/system evaluation mechanism.

This, in turn, is greatly aided by the existence of an adequate number of test methods that can give the performance data needed for evaluation determinations. Additionally, it is not unusual to find performance requirement statements written in terms of some test method. In the case of fire resistance requirements it is common to see them expressed in terms of time, such as a "one-hour" wall. In such instances, the requirement means that the construction must satisfactorily survive one hour in a controlled fire as described in a particular test method (such as ASTM E-119). Many other similar examples can be shown illustrating the close relationship between the expression of performance requirements and test methods.

Participants in this project recognize that the need for test methods demonstrates the dependence of this project on the various national building research centers and their international organizations--CIB and RILEM. The development and compilation of the data needed for the test methods, in the number and of the quality adequate for the international project, is known to require a well coordinated, collaborative effort among the several nations involved. It is difficult to imagine how this harmonization project can succeed without a support commitment from the national building research centers.

Delegates to this June 1976 meeting were duly impressed with the mechanism employed by the UEA (European Union of Agrément) in effecting national and international acceptance of building products or systems. This nine nation consortium is, in a skeletal way, accomplishing some of the objectives of this UN/ECE harmonization project.

\section{EUROPEAN UNION FOR AGREMENT (UEA) 12/}

Many countries have seen the need to have a procedure that would demonstrate the suitability, over time, of a building product or system being introduced for use in construction. The procedure that has been developed to cover this need within some of the European countries is now generally referred to as Agrement. The UEA is a nine nation (United Kingdom, France, Belgium, Spain, Italy, Federal Republic of Germany, Austria, Holland, Portugal) association of European Agrément authorities that operate national testing and evaluation mechanisms engaged in issuing technical assessments or

12/In Europe, the acronym for the European Union of Agrement is usually written as ${ }_{\mathrm{UE}} A_{\mathrm{tc}}$, derived from the French title - "Union Europeene pour I'Agrément technique dans la construction." 
Agrements for buildings, building components, or building systems. The Agrement procedures are intended to display the performance characteristics of new products (or old products used in new ways), supplementing the normal evaluation procedures that rely on standards or codes of practice. Since only favorable Agrements are issued, products or systems so covered satisfy applicable building regulations under application limitations stated in the Agrement.

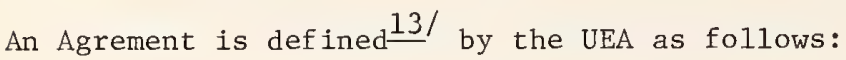

"Agrement is a favorable technical assessment of the fitness for use of new materials, components or systems, taking into account the safety, purpose and durability of the construction. The assessment relies as far as necessary on the opinion of impartial experts, based on as wide a range of laboratory and in situ experiments as possible."

"Technical assessment" as used here means the identification and measurement of all of the properties considered critical for a given class of products (such as windows). These properties are the environmental/human-use load factors for which reliable, impartial and comparable data must be obtained, preferably by tests or other reproducible measurement techniques designed to display a product's response to each of the required in-use properties identified.

One of the distinguishing facets of an Agrement is that it attempts to provide reliable technical information on the performance over time that reasonably can be expected of innovative building products or systems under specific conditions of use. It is this "performance over time" aspect that is the essential difference between the Agrément "technical assessment" and "certification to standards" approval systems. The former requires a large degree of expert judgment while the latter usually requires only the running of control tests identified in the standard and makes no attempt at determining whether or not the product covered by the standard will satisfy a given use condition.

When applying for an Agrement certificate, proponents are expected to state the intended end use or uses claimed for the product. It is on the basis of these claims, relative to a complete list of critical properties deemed essential for the particular class of products involved, that an individual Agrement evaluation program is developed. If the submittal is a window, for example, the issuing institution would go through the following steps leading to the issuance of an Agrement certificate:

1. Identify all of the relevant properties that an acceptable window is expected to address(resistance to water penetration, thermal conductivity, corrosion resistance, etc.) taking into account such factors as:
(a) Safety
(b) Habitability
(c) Durability
(d) Maintenance
(e) Practicability

2. Select or devise the tests or examinations required to display the responses of all windows to the properties identified in No. 1 above.

3. Subject the window submitted to the above required tests.

13/"Agrement and Technical Innovation" by T. P. R. Lant, The Agrement Board, Hemel Hempstead, Herts HP1 1DH, England. 
4. Submit the data gathered above to an assemblage of experts in windows for buildings.

5. Elicit an agreement from those experts regarding the performance suitability of the window as submitted including the pertinent manufacturing quality control requirements, site storage precautions, installation techniques that must be observed, and the use limitations that are made part of the conditions governing both the issuance of the Agrément certificate and the liability of the issuing organization.

With the noticeable drift towards a greater use of performance statements in building regulations, especially the use of "deemed-to-satisfy" language, nationally produced Agréments have continued to grow in popularity. There is even a noticeable trend among producers of long-established products/systems to seek Agréments because of their wide ranging, performance-based, end use assessments not usually provided by traditional standards. Since only favorable Agréments are issued, they are attractive as impartial reinforcements of a proponent's performance claims.

Because an Agrément organization does include an assessment of the durability of the product or system and because it usually accepts legal responsibility for its opinions, it is very careful in expressing the conditions under which the Agrément is granted. These conditions go beyond the usual scope of product standards in that they address such concerns as application/installation techniques and even such factors as job site protection (against rain or freezing, as an example) requirements prior to installation.

It is the successes attained at the national level that has prompted the evolution of an international Agrément program. The widening of national marketing areas brought about by national Agrement programs suggested the possibility of extending them even further through a similar international program. Informal, exploratory discussions among the heads of the various national Agrement institutions, urged on by the industries they served, gradually resulted in the formation of the UEA. What started out as informal arrangements between France and Holland in 1960 have now grown into the more formal nine nation consortium.

The long-range goal of the UEA is to establish a procedure whereby products covered by Agrement certificates issued by one of the members could be accepted by each of the participating national authorities for official approval within their regulatory systems. At the present time, the UEA is about as far along this road as it can go until performancebased, internationally harmonized building regulations begin to appear. However, the UEA has been able to develop an internationally acceptable (among the nine member countries) technical assessment program. In this case, the technical assessment is limited to the presentation of reliable data that is complete enough for evaluation purposes but leaves the analysis of the data and the acceptability determination of the subject entirely in the hands of the national regulatory institution. The fact that the UEA has achieved this much is a major accomplishment. Even this limited success illustrates the change taking place in national attitudes towards effecting improvements in international trade.

If a UEA member receives an application for a technical assessment of a product intended for international trade it will:

1. Assemble a recommended list of properties that must be measured.

-- Circulate this list among the UEA members until concurrence with its completeness is obtained.

2. Identify the test methods proposed to be used in measuring the responses of the product to the list of properties (utilizing ISO or regional standards, wherever possible).

-- Circulate this list of test methods among UEA members until general concurrence with the suitability of these test methods is obtained. 
3. Subject the product to the agreed-upon tests and assemble the resulting data in a technical assessment report.

4. Distribute these data to the other UEA members for their use in determining whether or not the data indicate compliance of the product with their applicable requirements.

Thus, a proponent can seek approval for his product from the regulatory authorities in any one of the UEA countries and have it evaluated by all on the basis of the data developed by the issuing Agrement authority. Acceptance of these data avoids costly duplicative testing.

The problem not yet completely solved by the UEA is that involving quality control. Regulations in some of the UEA countries require evidence that the product delivered to the job site is the same as that tested. In most cases the quality control agent chosen to ensure such production reliability must be approved by the national regulatory authority who usually has no mechanism for approving foreign institutions. This problem is prevalent throughout the UN/ECE region and is under study by both the UEA and the UN/ECE.

This UEA story was presented to the delegates at the UN/ECE June 1976 meeting on quality approval and control. It elicited a great amount of interest in that it seemed to provide the outline of a feasible system that could be further developed into a solution to this critical international problem. In addition to the quality approval and control aspects of the UEA operation, the methodology used to develop internationally acceptable performance criteria (properties) for classes of products and for the identification and/or development of similarly acceptable test methods also offers the UN/ECE governmental agencies and the ISO standards committees a body of experience of great value.

Both Sweden and the Union of Soviet Socialist Republics (USSR) showed considerable interest in the UEA program and suggested that the UEA put on an explanatory program for the benefit of those who wished to know more about the details of the UEA operation. This meeting never materialized primarily because of the reluctance of some UEA members to consider the further expansion of present UEA operations. This reluctance seems to be based on the following concerns:

1. Difficult operational modifications to existing national programs and to international arrangements are usually required for each new country added. The more countries that are added the more difficult it becomes to negotiate new international agreements able to encompass the unique national features involved.

2. The countries now involved in the UEA are members of the EEC, the European Economic Community (Common Market), and the UEA is providing a useful service in this context for the construction industry in the EEC.

3. Existing members are somewhat fearful of trying to accommodate their operating program to the needs of giants like the USA and the USSR.

Separate interviews with two prominent UEA spokesmen resulted in their advancing the idea of the USA undertaking the development and operation of a regional version of the UEA program (to include interested South American countries and Canada) that might be aimed at the establishment of reciprocal arrangements with the UEA. Whether such a program would produce the greatest benefits to the USA is a proper subject for a separate study. It remains that the UEA is an extremely interesting operation that could offer a feasible solution to the UN/ECE problems with quality approval and quality control. 
It would also seem that a serious review of existing UEA practices would be of great benefit to the International Organization for Standardization (ISO). The existing UEA performance criteria or properties for classes of products, already possessing a degree of international approval, could become useful drafts of Iso performance requirement standards. Similarly, the great amount of work accomplished by the UEA in the area of test methods should prove extremely useful in enabling the ISO to respond to the standards needs expressed by the UN/ECE.

The importance of the function now being performed by the UEA to the success of the UN/ECE performance-based project cannot be overemphasized. Both the Helsinki Agreement and the proposed GATT Standards Code call attention to the need for a similar international evaluation/certification mechanism. On this basis, it would seem that if the institutional structure and procedures of the UEA cannot be expanded to include additional nations then a UEA replacement will have to be developed.

\section{THE INTERNATIONAL ORGANIZATION FOR STANDARDIZATION - ISO}

ISO is the specialized international institution for standardization. At present, it includes members representing 82 countries. As distinct from such regional (but international) standards organizations as CEN (European Committee on Standardization), the work of ISO is aimed at worldwide agreements on truly international standards.

The scope of the work of ISO covers both technical and nontechnical standards. However, it is not active in the electrical field. International standards in that area are the responsibility of the International Electrotechnical Commission (IEC). ISO procedures enable producers, users, Governments, and members of the scientific community to participate in the development of international standards.

Following a meeting in London in 1946, delegates from 25 countries decided to create a new international organization "whose object should be to facilitate the international coordination and unification of industrial standards." The ISO began to function officially on February 23, 1947. It is a private organization dependent on the financial support given by its member bodies.

A member of ISO is defined as the national body "most representative of standardization in its country." It follows that only one such body from each country is accepted for membership in ISO. The American National Standards Institute (ANSI) is the USA member body. Member bodies are entitled to participate and exercise full voting rights on any ISO committee and are eligible for Council membership and have a seat in the General Assembly. ISO contacts are also funneled through the member bodies.

More than 70 percent of the Iso member bodies are governmental institutions or organizations incorporated by public law. The remainder tend to have close links with public administration groups in their respective countries. By December 1976 there were 63 member bodies in ISO.

A correspondent member is normally an organization in a developing country which does not yet have its own standards body. Correspondent members do not vote in the technical work but are kept fully informed. Nearly all present correspondent members are governmental institutions. By December 1976 there were 19 correspondent members of ISO.

The technical work of ISO is carried out througt Technical Committees (TC's). The decision to set up a Technical Committee is taken by the ISO Ccuncil, which also determines the scope of the committee. Within this scope, the TC determines its own work program.

Technical Committees may create Subcomittees (SC's) and Working Groups (WG's) to cover different aspects of the work. Each TC has a secretariat, assigned to an ISO member body. ANSI holds 18 secretariats for TC's and 57 SC secretariats. The Association Francaise de Normalisation (AFNOR), the French standards organization, holds the largest number of secretariats, a total of 175, 32 of which are for full Technical Committees (TC's). 
Secretariats for TC's are assigned by the ISO Council while parent committees usually assign secretariats for Working Groups (WG's). At the end of 1976, the we were 151 TC's, 548 SC's

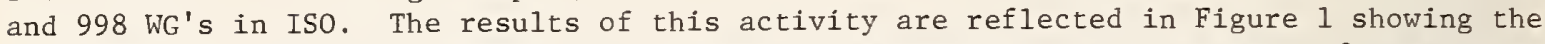
tremendous growth in the number of published ISO standards. Forty percent of the current total of over 3000 ISO standards have been produced since 1973. In addition, it is estimated that about 3000 draft standards currently are in the ISO standards pipeline.

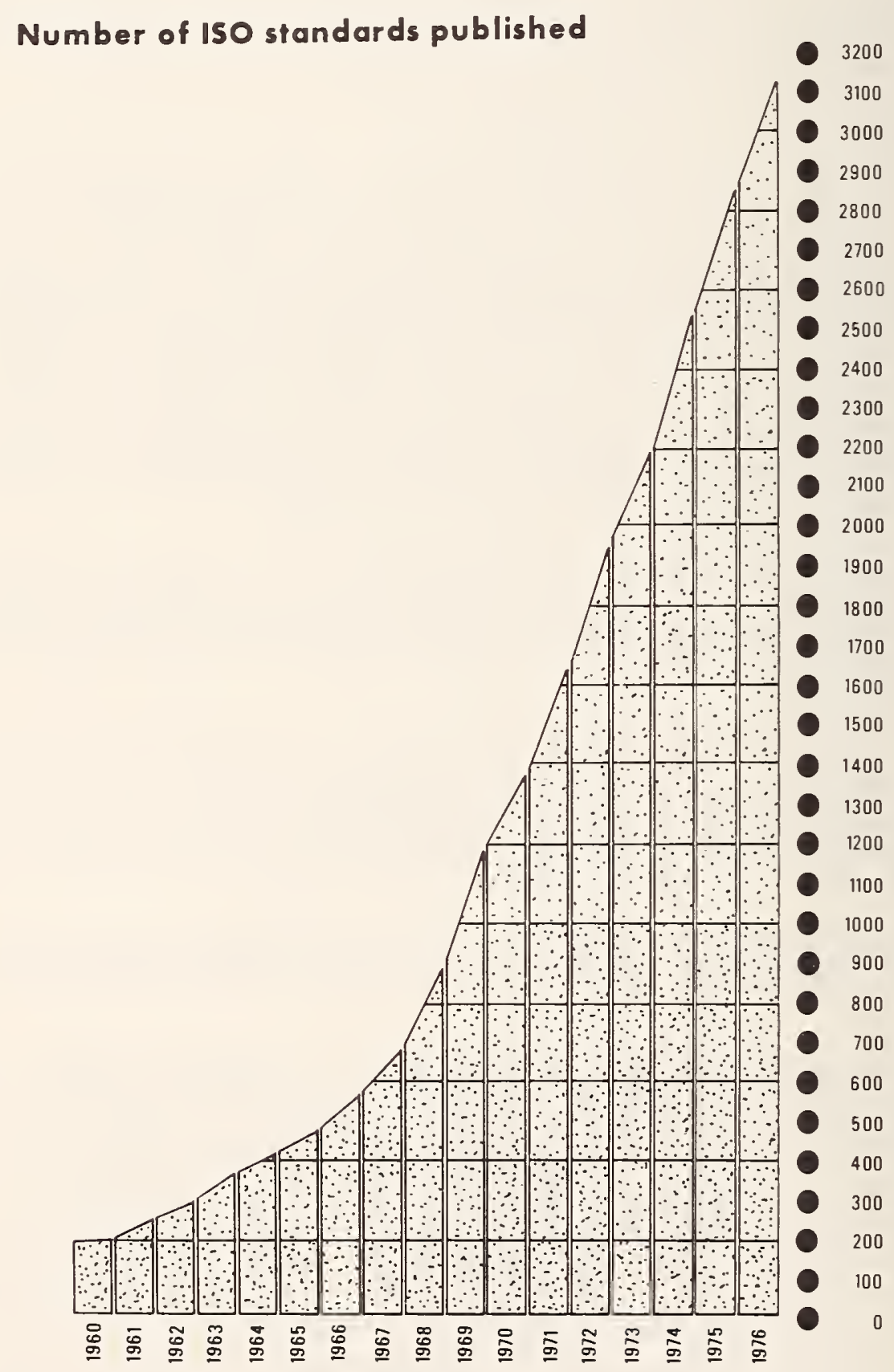

Figure 1 
To better comprehend and serve the standards needs of a particular field, such as those in the fragmented construction community, ISO may create Technical Divisions (TD) which can be likened to standards development management groups. ISO Technical Division 3-Building/Construction-- has been formed and is operating with this objective.

Member bodies who decide to take an active part in the work are designated as P-members (participating) of the committee. They have the right to participate in meetings and to vote. One of the P-members is designated to act as the secretariat of the committee. Member bodies which wish only to be kept informed of the work of a Technical Committee or Subcommittee are registered as 0 -members (observers). The personal representatives of $P$ or 0 members are selected and accredited by each national standards institution (member body) interested in the work of the committee. A11 USA representatives are accredited by ANSI.

An International Standard is the result of an agreement developed among ISO member bodies. The first step towards an International Standard takes the form of a Draft Proposal (DP). This document, the preparation of which is usually considered to be the responsibility of the secretariat, is circulated for study within the TC. When agreement is finally reached within the TC, the document is sent to the ISO central secretariat for registration as a Draft International Standard (DIS). The DIS is then circulated among all ISO member bodies for ballot. If 75 percent of the votes cast are in fayor of the DIS, it is sent to the ISO Council for acceptance as an International Standard.14

\subsection{ISO - UN/ECE Working Arrangements}

The ISO has been singled out by the governmental bodies in the UN/ECE as the source of the great number of international standards required for the building regulatory harmonization project. The ISO Council is very sensitive to this request. Being a nongovernmental institution, ISO Council members are pleased that these governmental bodies elected to make use of ISO consensus standards procedures. It is well known that some governmental regulatory authorities are reluctant to accept consensus standards as the basis for their regulations, even in the free-market countries of western Europe. The opinion advanced for this reluctance are:

1. It takes far too long to develop an ISO standard.

2. The compromises required to gain agreement detract from the usefulness of the resulting standard.

3. The format and language used in standards are not always suitable for regulatory purposes.

In spite of the fact that some individuals in the UN/ECE group tend to feel this way, the majority have, on the basis of the ISO potential, decided to initiate this huge building standards development program through ISO. Negotiations between the UN/ECE and ISO that led to this working arrangement also clarified the role of each. ISO spokesmen pointed out that ISO is not a "standard store" where one simply walks in and orders a shelf-item standard. It is a managed set of procedures whereby those seeking an international standard can, through their own efforts, develop one. While admitting that more efficient procedures are needed, ISO indicated that if governmental bodies were not happy with the usual standards development pace, governments have a responsibility to ensure more and better participation by their national delegates to ISO standards committees. ISO feels that if governments want higher quality international standards, they should make greater use of their governmentsupported building research programs in order to supply the high quality, objective data needed for international standards.

14/The above explanatory information has been distilled from similar material contained in the ISO Memento for 1977. The latter can be obtained from the American National Standards Institute, 1430 Broadway, New York, New York 10018. 
This exchange of views reflects a real life relationship between the construction communities and their governments, especially in the free market countries. The fragmented, decentralized structure of the industry and the vital service it provides seems to demand government sponsored building research centers. Additionally, the establishment and operation of viable national building standards development programs seems to be dependent on governmental participation and support. In the controlled market countries the same situation prevails for both building research and building standards development, though for different reasons. An international building standards development program is recognized to be even more dependent on government participation and support.

Leaving the UN/ECE to struggle with this standards committee-support/participation problem, the ISO has undertaken strong measures to put its own house in better order. It is recognized that the UN/ECE request is the most comprehensive and best organized standards development program ever offered to a standards organization. Although the UN/ECE has not yet formulated a schedule defining when these standards are wanted, it did give Iso a clear statement of the scope and thrust of its requirements. The UN/ECE wants from ISO:

(a) An international standardized methodology, terminology and format for use in writing performance-based building regulatory standards.

(b) International standards describing a recommended range of acceptance levels for performance-based regulatory requirements for buildings and building components.

(c) The performance test methods to be used to display product/system responses to the stated requirements.

(d) Worldwide, basic technical design-data standards (wind loads, earthquake loads, snow loads, etc.).

The center for the "strong measures" ISO is undertaking in response to this UN/ECE request is located in Technical Division 3 - Building/Construction. As mentioned earlier, Technical Divisions (TD's) are employed in a standards development management fashion. Iithout usurping any of the planning and coordinating functions carried out by the main Iso planning committee --PLACO-TD 3 is expected to build up the details of PLACO-established policies in the building standards field.

TD 3, with the understanding help of the ISO central secretariat has:

1. Developed a draft of an ISO Policy Statement in the field of building standards.

2. Established the rationalizing concept of three levels of international building standards.

3. Acted to change and broaden the membership base of TD 3 .

4. Accepted the responsibility to develop ways of improving the technical coordination of ISO standards in the building field.

5. Established a Divisional Council.

6. Recommended that the basic performance-methodology standards be assigned to Iso Technical Committee (TC) 59 - Building Construction. 


\subsection{Statement of ISO Policy in the Field of Building}

After the consideration of several drafts of an ISO Policy Statement, the draft document introduced at the February 1976 meeting (in Rotterdam) of TD 3 was finally accepted. Because of the importance of this statement in understanding the nature of the ISO commitment in this subject area, it is presented here in its entirety:

\section{"ISO Buizding Standards POLicy}

With the growing tendency in the buizding field to use prefabricated, more sophisticated and expensive components, a significant international trade in building materials and components has developed. Intemational trade of such products is, however, hampered, made more costly, or even blocked completely, when differences exist between the standards and regulations of the exporting and importing countries. In order to facilitate the intemational exchange of goods and services in the building field, national building standards and regulations must be harmonized.

In recent years it has become more widely recognized that building standards and regulations should be expressed in terms of functional requirements of the completed building and in terms of performance requirements of its components. This new concem for effecting improvements in international trade through performance standards calls for a closer cooperation among research institutions, governmental organizations and industry associations and gives building standardization a more global aspect.

International standardization in the building field has, therefore, become increasingly urgent as a measure for direct and indirect promotion of international trade of building products and equipment. International standards also favour intemational cooperation; they promote the spreading of similar building techniques and the exchange of information, and facilitate the multinational activity of design, engineering, and consultant firms.

In order to guide its activity in the field of building, ISO has adopted the following principles and procedures:

1. Any standardization in the building field must recognize that a building is constmcted to meet, above all, the needs of the human being, particularly with respect to health, comfort and safety. This can best be realized in expressing international building standards as far as possible in terms of performance requirements for building elements, components and materials. This will give intemational building standards worldwide relevance in that they are formulated irrespective of the materials available in different regions of the world.

2. In order to obtain worldwide application, international building standards will further have to take account of different climate and other regional conditions such as available know-how and different stages of technical and economic developments. Whenever feasible, intemational building standards should include different requirement levels for application in different regions according to prevailing conditions.

3. ISO wiIl consider the needs of intergovernmental organizations concemed with building regulations in order to comply with the accepted policy that such regulations should make reference to Intemational Standards, or intemationally harmonized national standards, as appropriate. 
4. One of the primary objects for intemational standardization must be the harmonization of general principles and fundomental standards for building and civil engineering stmuctures. In order to meet requirements of intergovemmental organizations concemed with the hamonization of the technical content of building regulations, ISO will have to find means to accelerate its work in this field.

5. Standards for general methods of test or assessment should be established for groups of products, possibly including classification of products and should be based on the standardization of performance requirements.

6. A prerequisite for a successful industrialization in the building field on an intermational scale is the establishment of a coherent system of international building standards. In order to establish such coherency, the ISO programme in the building field must be based on an overall view of the building and civil engineering problems including existing technical knowledge and experience.

7. The establishment of a coherent set of intemational building standards requires, inter alia, that all technical conmittees active in this field respect a system of levels of standards to secure close coordination in the sense that a standard on a certain level must always conform with related standards on a more general level. For this purpose, three levels have been established:

FUNDAMENTAL STANDARDS: General principles and fundamental standards for building and civil engineering structures.

WIDE-RANGING STANDARDS: Standards for groups of products concerning preferred dimensions, performance requirements, general test methods, etc.

SPECIFIC STANDARDS: Descriptive standards for specific building products, materials or components concerning properties, test methods, etc.

8. ISO standards must further be dynomic and consideration must be given continuously to research and development. The interrelation between building standards, regulations and research must be studied in collaboration with other intemational bodies concemed.

9. In order to improve the efficiency of intemational building standardization according to the criteria set forth in this Statement, the active cooperation and support of governments and intergovemmental organizations which have building standardization on their programe should be sought. "II

\subsection{Three Levels of International Standards}

The standards development work in ISO is carried out by Technical Committees (TC's) under the general guidance of secretariats who are P-members of ISO. This decentralization brings into play experts from all over the world and contributes to the global aspect of the work of ISO. It is recognized that it also contributes to the problem of maintaining technical coherency among ISO standards. Technical intercommunication among TC's has not been as good as expected. A committee developing standards for windows used in

15/Copies of this Policy Statement in the field of building may be obtained from the International Organization for Standardization, 1, rue de Varembé, 1211 Geneva, Switzerland. 
buildings could end up with more (or less) rigorous window performance demands than might be found in standards for the class of buildings in which the windows would be used. Similarly, the dimensions chosen for the building standards or the window standards may ignore the fundamental, level 1, dimensional coordination standards developed by ISO/TC 59 .

TD 3 introduced the three-level concept as an aid to these separate ISO committees to enable the participants to be aware of the familial ties of their standards development work. This three-level concept can be selectively applied to various groupings of naturally related standards activities. It could be used, for example, to show that a construction terminological standard would be a level 1 standard in relation to a standard for dwellings (level 2) or a standard for dwelling windows (level 3). In the same context, a general window standard might be usefully classed as a level 1 standard in relation to a standard for glazing materials (level 2) or glass--one kind of a glazing material (level 3). The concept should work as well going from level 3 to 2 to 1 as from 1 to 2 to 3 . TD 3 , exercising its management role, and using this three-level tool, now can systematically monitor the work programs at each level so as to reveal technical inconsistencies and coordination deviations needing corrective action.

\subsection{Broadened TD 3 Membership Base}

Revisions to internal operating procedures of ISO resulted in recent changes in the functions assigned to Technical Divisions, and especially to TD 3. Formerly, membership in TD was limited to representatives of those P-members holding secretariats of ISO committees. TD 3 was considered a forum whereby these secretariats could coordinate their standardization activities. Difficulties with this mechanism for solving coordination problems resulted in a reshuffling of ISO procedures that has changed TD 3 considerably. Membership in TD 3 is now open to all P-members interested in Building/Construction regardless of whether or not they hold a secretariat for an Iso committee. A new liaison status has been set up to encourage the participation of international organizations (of a global rather than regional nature) interested in the field of worldwide building standards. The International Council for Building Research Studies and Documentation (CIB), a worldwide organization of building research laboratories (and a major source of standards data), is now a member of TD 3 . The International Union of Testing and Research Laboratories for Materials and Structures (RILEM), an organization similar to the CIB but specializing in building materials and test methods, has also become a member of TD 3. It is interesting to note that the European Committee for Standardization (CEN) applied for membership but was denied because of the regional nature of CEN standardization activities.

The new TD 3 functions are centered in the planning and programming areas of building standards activities, while its former coordination function is now largely in the hands of the ISO Council. TD 3 is not expected to try to solve standards coordination details but is expected to identify areas where technical coordination is needed and to suggest methods by which secretariats themselves can carry out detailed coordination activities. The three levels of standards, discussed previously, is one of the methods developed by TD 3 for this purpose.

\subsection{TD 3 and the Technical Coordination Problems}

Another kind of coordination problem exists among the decentralized ISO committees that is often evident in national standards activities also. This relates to technical inconsistencies that arise among standards for products of the same end-use class. Sweden has called attention to the problem area in relation to several Iso standards committees dealing with pipes used in construction (TC 5 metal pipes, TC 77 asbestos cement pipes and TC 138 dealing with plastic pipes). Each of the standards developed by these committees is satisfactory if considered singly. Taken as a group, however, their technical incompatibility seriously affects their usefulness to designers. Not only does the basic descriptive terminology differ among these standards, but there is even a dissimilarity in 
the standard dimensioning practices used. Standard sizes of plastic pipes are determined on the basis of outside pipe diameters while those given for asbestos cement (and other) pipes relate to the inside diameter. Test methods used in the standards to display physical properties critical to the proper use of all such pipes (crush resistance, burst pressure, expansion/contraction, etc.) all differ so that the data conveyed by these standards to the user is not comparable. Additionally, some of the properties subjected to measurement in one standard may be ignored in another. Selecting a pipe made of a material having a combination of properties most suitable for a particular design consideration becomes practically impossible on the basis of the data given in the standards.

Product/system evaluation processes that form a central part of a performance-based regulatory system, are most efficient when they can deal with standards having a high degree of technical coordination. TD 3 has recognized the pressing need for ISO to produce standards possessing this quality so as to assure their usefulness to the UN/ECE harmonization project.

\subsection{ISO/TD 3 - Divisional Council}

As an important part of the ISO planning in response to the UN/ECE request for internationai building standards, TD 3 undertook the establishment of a Divisional Council. ISO authorized the establishment of such Councils (which resemble executive or steering committees) back in 1966, but TD 3 is the first of the four present ISO Technical Divisions $16 /$ to make use of this standardization management tool.

The concept of a TD 3 Divisional Council was introduced at the Rotterdam meeting of TD 3 (February 1976) by the ISO Central Secretariat as a result of a recommendation by a special TD 3 consultative group. The purpose of the Council as proposed is:

1. to consider fundamental questions of international standardization in the context of overall building policy;

2. to assess needs and requirements for international building standards;

3. to consider problems of cooperation with other international organizations;

4. to study the feasibility of new work in the field of building; and

5. to act as needed between meetings of TD 3 in accordance with the tasks assigned to Technical Divisions.

Membership in the TD 3 Divisional Council is on a personal, not an organizational, basis. Members are selected for their personal knowledge of building standards and are appointed by TD 3 for a period of three years with acceptance of the appointment contingent on the ability to attend four meetings a year (usually in Geneva). The first members of the TD 3 Divisional Council (the first in ISO) are:

Chairman: Mr. 0. Hedlund (Norway)

Members: Professor G. Blachere (France)

Professor Dr. S. Kajfasz (Poland)

Mr. C. Mahaffey (United States)

Mr. L. Nфrgaard (Denmark)

Dr. W. Rohrbach (Germany)

Professor Dr. Gy. Sebestyen (Hungary)

Mr. V. I. Sychev (Russia)

Correspondent Member: Professor T. Sakata (Japan)

Secretary: Mr. B. H. Holloway (International Organization for Standardization)

16/TD 1 - Mechanical/Engineering

TD 2 - Agriculture

TD 3 - Building/Construction

TD 4 - Distribution of Goods 
The need for a Divisional Council became apparent after the reorganization of TD 3. Broadening the membership opportunities in TD 3 to include not just P-members holding committee secretariats, but all ISO members interested in construction, significantly increased the size of TD 3. As a consequence of this change, twenty delegations involving more than 50 people from all over the world were in attendance at the February 1976 meeting of TD 3 (held at the Bouwcentrum in Rotterdam). The new size of TD 3 was considered too unwieldy for effective planning purposes and was a primary factor leading to the approval of the formation of the Divisional Council by TD 3 .

At this meeting, TD 3 asked its newly formed Divisional Council to come forward with proposals concerning:

1. How to achieve a coherent set of international building standards.

2. How to ensure that all international building standards reflect an overall view and a common concept of building problems.

3. How to improve the ISO working methods in the building field to enable ISO to meet the needs for international building standards, particularly those identified by the UN/ECE.

Five meetings have been held by this Divisional Council since its inception. The next one is scheduled for June 1978 in conjunction with a series of meetings involving the UN/ECE, ISO and many of the several technical, governmental and nongovernmental, international organizations related to the field of building standards.

Out of these Divisional Council meetings has come an important study paper entitled "General Concept for the Improvment of the Efficiency of International Standardization."17/ The paper addresses all three of the charges given the Divisional Council by TD 3 in Rotterdam. It suggests that a major improvement in both the overall technical coherency of standards and in the time required to produce a standard could be achieved through the establishment of an international building standards Center to be attached to the ISO Central Secretariat in Geneva. The major function of the Center would be the development of the initial drafts of needed standards. The manner in which drafts are now being prepared is considered to be unacceptable, for two reasons:

(a) it takes too long to get these drafts prepared and distributed for consideration by the committee; and

(b) not enough effort is expended to ensure that the draft is technically consistent with existing standards or other drafts in preparation.

Currently the preparation of drafts is one of the responsibilities of committee secretariats. Too often the drafts introduced are simply a standard in use in the country of the secretariat. While this method may have been useful in prior years, the UN/ECE program is outlining the development of an entirely new building regulatory system intended to become a model for national adoption. This system requires a different approach aimed at producing a series of technically related international standards specifically tailored to the needs of a new performance-based regulatory system. The ISO study paper suggests the establishment of a group of standards-writing experts, knowledgeable in the construction disciplines involved, who can cooperatively prepare the drafts of needed standards from a coordinated, system-oriented, internationally-objective viewpoint. This group would be employed in this manner in order to speed the ISO response to the UN/ECE request for the more rapid development of better coordinated international standards. Because such a Center will significantly increase the financial support required of the participating countries, the matter is still under consideration.

17/Copies of this paper may be obtained from the International Organization for Standardization, 1, rue de Varembe, 1211 Geneva, Switzerland. 


\subsection{Technical Committee (TC) 59 - Building Construction}

If one were to single out the most important ISO standards committee pertaining to the building industry, it would have to be TC 59. This committee, initiated in 1947, has a scope so large as to cover almost all of the standards needs of the building industry. It reads as follows:

Standardizations of:

1. Terminology in the construction and civil engineering industry.

2. General geometric requirements for buildings, building elements, components and products, including modular coordination and its basic principles, joints, tolerances and fits.

3. Other general performance requirements for buildings and building elements (user needs) including the coordination of these with performance requirements of building components and products to be used in the construction and civil engineering industry.

Excluded are:

-- Bases for design of structures (TC 98)

-- Particular geometric requirements and performance requirements of building components and products which are in the scope of separate ISO Technical Committees.

Until 1974, TC 59 had been concerned primarily with the development of standards pertaining to modular or dimensional coordination. The whole series of international standards (13 in all) related to this subject (including the one establishing $100 \mathrm{~mm}$ as the basic international dimensioning module) were produced by TC 59 and its several subcommittees and working groups.

A listing of these subcommittees (SC) and working groups (WG) follows:

Subcommittee (SC) or Working Group (WG)

*WG 1
SC 1
WG 1
WG 2
WG 3
WG 4
SC 2
WG 1
SC 3
SC 4
WG 1
WG 2
WG 3

SC 5 $\underline{\text { Title }}$

Physically handicapped

Dimensional Co-ordination

Preferred sizes

Multimodules

Sub-modules

Location of fixings

Terminology, symbols and unification of language

Terminology

Functional/user requirements and performance in building construction

Limits and fits in building construction

Tolerances in building, general principles

Measurement procedures in building

Classes of tolerances for the building industry

Joints
Secretariat

Sweden
Sweden
Denmark
Soviet Union
United Kingdom
France
France
Norway
United Kingdom
Denmark
United Kingdom
Sweden
Germany
France

*The Working Group on the physically handicapped is now being formed. It is novel in that it is a working group attached directly to TC 59 as a whole rather than to a subcommittee as is the usual Iso operational relationship. 
Structures, external envelopes, internal subdivisions

Prefabricated components for floor and roofs, structural framing components and vertical loadbearing components

Curtain walling and panels and vertical non-loadbearing components

Stairs and stair openings

Coverings

Floor and wall finishes

Ceiling components

Equipment, services and drainage

Bathrooms and toilets

Accommodation ducts

Jointing products

Kitchen equipment

Test methods and performance requirements

Service zones

Activity spaces

Mechanical transporting systems

Lifts on board ships

Signalling and control devices
Germany

Soviet Union

France

Sweden

France

France

France

France

France

United Kingdom

Germany

Sweden

United Kingdom

United Kingdom

Sweden

France

Demark

France

The most active subcommittees are:

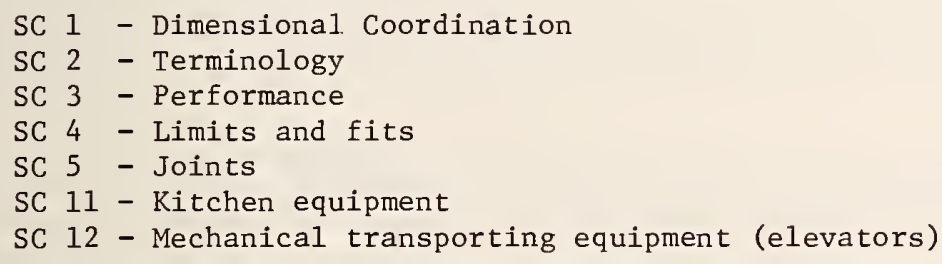

A new committee, TC 162 - Doors and Windows, formerly was a very active subcommittee of TC 59, but was set up as a full Technical Committee in 1975. Because of the great amount of activity in SC's 11 and 12, it would not be surprising if they too became full TC's in the near future.

The 13 existing ISO standards produced by TC 59 were developed by the following subcommittees:

\begin{tabular}{|c|c|c|}
\hline$\underline{\mathrm{SC}}$ & $\begin{array}{l}\text { ISO Standard } \\
\text { Number - Date }\end{array}$ & Title \\
\hline \multirow[t]{8}{*}{1} & $1006-1973$ & Modular Coordination - Basic Module \\
\hline & $1040-1973$ & $\begin{array}{l}\text { Modular Coordination - Multimodules Horizontal Controlling } \\
\text { Dimensions }\end{array}$ \\
\hline & $1789-1973$ & $\begin{array}{l}\text { Modular Coordination - Storey Heights and Room Heights for } \\
\text { Residential Buildings }\end{array}$ \\
\hline & $1790-1970$ & $\begin{array}{l}\text { Modular Coordination - Reference Lines of Horizontal } \\
\text { Controlling Coordinating Dimensions }\end{array}$ \\
\hline & $1791-1973$ & Modular Coordination - Vocabulary \\
\hline & $2776-1974$ & $\begin{array}{l}\text { Modular Coordination - Coordinating Sizes for Door Sets - } \\
\text { External and Internal }\end{array}$ \\
\hline & $2777-1974$ & $\begin{array}{l}\text { Modular Coordination - Coordinating Sizes for Rigid Flat } \\
\text { Sheets Used in Building }\end{array}$ \\
\hline & $2848-1974$ & Modular Coordination - Principles and Rules \\
\hline 4 & $1803-1973$ & Tolerances for Building - Vocabulary \\
\hline 5 & $2444-1974$ & Joints in Building - Vocabulary \\
\hline & $2445-1972$ & Joints in Building - Fundamental Principles for Design \\
\hline & $3447-1975$ & Joints in Building - General Check List of Joint Functions \\
\hline 11 & $3055-1974$ & Kitchen equipment - Coordinating Sizes \\
\hline
\end{tabular}


Most of the standards are either descriptions of the basic dimensional coordination principles involved or the general application of these principles to the sizing of buildings or building components. It is expected that while refinements will continue to be made to the basic principle standards, a greatly stepped up activity will take place in the application of these principles to specific subject areas. It is not expected that the several TC 59 Subcommittees will produce detailed specification standards describing the fabrication of the products they address. They will establish the overall dimensioning techniques for kitchen equipment, for example, but will not become involved in specifying cabinet joining details. When that kind of standardization is required, TC 59-SC 11 may be established as a separate Technical Comittee.

A very great contribution to the dimensioning standards prepared by TC 59 was made by the committee known as the International Modular Group (IMG). This committee, originally an ad hoc group of experts doing prestandardization research into the principles of dimensional coordination, is now a formally organized Working commission in the CIB. Its CIB designation is $\mathrm{W}-24$. The IMG is still an active and important research arm of TC 59. It presently is engaged in preparatory work leading to the development of international standards for tolerances, limits and fits.

Currently, a very important TC 59 activity is centered in SC 3 - Performance. This comittee is charged, initially, with developing the basic ISO standards describing the methodology, terminology, and format to be used in the development of internationally harmonized building regulatory systems. SC 3 is a new committee, formed in February of 1975, specifically for the purpose of centralizing the ISO response to the UN/ECE performance standards request. The Secretariat of SC 3 is held by the United Kingdom.

The SC 3 has formed UG 1 and given it the task of defining the methodology to be used. The IJG 1 is attempting to define appropriate classes of buildings and building components and to identify the physical properties of each that are to be measured in subsequent standards.

Studies conducted by WG 1 , and drafts presented for consideration are beginning to resemble the Attribute-Element matrix developed by the NBS Center for Building Technology (NBS/CBT) for Operation BREAKTHROUGH. A rapporteur has been named to study the format problem and to make recommendations to SC 3. This rapporteur, Mr. C. J. Teeks of Fixeter, England, has investigated several varieties of formats for performance standards in use throughout the world. At the March 1977 meeting of SC 3, Mr. Weeks chose to recommend the adoption of a format closely resembling that developed by the NBS/CBT. This proposed format was accepted by SC 3 and is now being developed into a Draft International Standard (DIS) by Mr. Weeks.

During the deliberations of WG 1 and the studies of the rapporteurs, certain key terms in this new performance language are being identified. This list of terms is being coordinated with, and included in, the building terminology being standardized by TC 59/SC 2 . It is not expected that SC 3 will develop a separate terminological standard.

The SC 3 is finding it difficult to confine itself to the development of the basic methodology standards. The actual application of the standards is beginning to seem inseparable from the methodology being developed. The methodology for stating the appropriate performance requirements can be fashioned around either of two major approaches to building regulatory systems. In the United States (and many other countries) building regulations are usually designed around construction disciplines (building codes, plumbing codes, electrical codes, elevator codes, etc.). The model codes and usually the actual building regulatory departments within a particular U.S. jurisdiction are organized in this manner. Conversely, the present Federal regulations for mobile homes cover all of these discinlines in one document.

The SC 3 can develop its methodology for either of these tro approaches, by aiscipline or by occupancy classification, but the governmental regulators in the UN/ECE must decide which of these two ways is most suitable for their harmonization project. 
There are some participants in this project who are not convinced that it is possible, at this time, to develop performance requirement standards for whole buildings. This position is based on their belief that adequate test methods for measuring the performance of whole buildings do not exist and are not likely to be developed, at least not in the near future. They prefer the development of performance requirements for building segments, such as roofs, floors, load bearing walls, doors, windows, stairs, elevators, etc. This approach would require code promulgators to organize their documents in a variety of ways, all of which would be based on the referencing of appropriate ISO performance requirement standards. These divergent views have to be resolved by the UN/ECE Working Party if a coherent international performance standards development program is to flourish.

One thing that members on both sides, the regulatory officials and standards writers, have agreed upon is that ISO performance standards should present a recommended range of acceptance values. More precise values would be established by national standards bodies. In the case of fire resistance requirements, the ISO standard would state, for example, a recommended acceptance range of 1 to $1-1 / 2$ hours and identify the test method (such as ISO 834-1975) on which the performance measurement is based. To be "harmonized," a related national standard should fall within the range of the ISO model and make use of the same test method.

TC 59/SC 3 is making relatively good progress, but it has a long way to go. It is tackling an enormously complex subject area that could have a revolutionary impact on national building regulatory systems. In the building standards area, SC 3 is establishing one of the principal technical bases for realizing the economic thrust of the Helsinki Agreement and the trade standards mechanism sought by the GATT negotiators. The importance of the work of SC 3 is matched only by the companion UN/ECE efforts in establishing international procedures for accepting national quality approval and quality control systems. The impact of both activity areas will be felt throughout the world building community for a long time to come.

\section{EXISTING U.S. RELATIONSHIPS WITH ISO AND THE UN/ECE}

\subsection{ISO}

ANSI, the American National Standards Institute, is the U.S. member body in ISO. Although ANSI is a private organization, U.S. Government officials participate with it in ISO activities. All representations of U.S. interests in international standards activities in ISO are organized under the procedures developed by the contributing members of ANSI. These members include all of the major U.S. standards generating organizations--American Society for Testing and Materials (ASTM), American Society of Mechanical Engineers (ASME), American Society of Heating, Refrigerating and Air-Conditioning Engineers (ASHRAE), National Fire Protection Association (NFPA), etc. These procedures are designed to permit the systematic development of a U.S. "position" relative to ongoing or proposed international standards activities. These procedures are centered around the use of national committees called USA Technical Advisory Groups (USA TAGs) for the development of such "positions."

USA TAGs are established by ANSI when concerned individuals or organizations decide that an ongoing or proposed international standards activity is of national interest and subsequent investigative studies by ANSI indicate sufficient U.S. interest to warrant participation.

A USA TAG is usually organized by an ANSI-approved organization able to supply and support the administrative needs of the committee. These sponsoring organizations, called Administrators, are expected to insure that:

(a) all USA organizations concerned with the standardization subject are given an opportunity to participate;

(b) USA "positions" or initiatives are developed and properly relayed to the ISO Committee; 
(c) the TISATAG Drovide its proper share of ANSI's administrative costs pertaining to ISO activities; and

(d) serious attention is given to the matter of attendance at international meetings by properly briefed USA TAG representative.

Gaining participation of construction-related USA TAG activities has not been easy. Because of the differences in the measurement system and present difficulties in establishing foreign markets, most members of the U.S. building community have found it more rewarding to concentrate their standards activities at home. This has been particularly true in standards activities dealing with such basic subject areas as the principles of (metric) construction dimensioning--TC 59, or in the standards management functions of TD 3 , both of which tend to be looked upon as "foreign" standards activities.

The NBS Center for Building Technology accepted ANSI's request to be the Administrator of the USA TAG for TC 59 in 1974. Since that time, the NBS/CBT has been unsuccessful in assembling a U.S. committee able to relate to the broad scope of TC 59. As the U.S. metrication movement picks up, it is believed that the usefulness of active participation in TC 59 activities will become more widely appreciated. When that happens it should become relatively easy to organize an appropriate IC 59 USA TAG. During this interim, pre-SI period the NBS/CBT has been in attendance at several IC 59 meetings during the years 1974-77. This has been a monitoring rather than a participation activity since there has been no mechanism for developing a USA position on TC 59 agenda items.

The United States did not attend the meetings of TD 3 until 1974. This was the beginning of the NBS/CBT's research into the nature and extent of ongoing international

building standards activities. The initial information gathered by the NBS/CBT indicated that TD 3 could be expected to become important to a metric building world and that it would be desirable to continue monitoring the meetings of this newly reorganized committee. As a result, the NBS/CBT, through ANSI, has been in attendance at nearly all of the TD 3 meetings since 1974. The NBS/CBI plans to continue this information gathering activity as a service to the U.S. construction community. Hopefully, as the U.S. metrication effort picks up momentum, appropriate national comittees can be formed, permitting a broad based U.S. participation in these important international activities.

\section{$8.2 \mathrm{UN} / \mathrm{ECE}$}

The U.S. Department of Housing and Urban Development (HUD) is accredited by the U.S. Department of State to represent the U.S. in the UN/ECE Comittee on Housing, Building and Planning (HBP). The HBP is the parent body of the Working Party on the Building Industry and the latter is directly involved in the building regulatory project. The HUD Office of International Affairs has been coordinating U.S. participation in this UN/ECE project. HUD staff members represented the U.S. at the 1973 meeting in London that marked the official launching of the harmonization project. Since that time, many HUD staff members have been in attendance at the numerous UN/ECE meetings pertaining to this subject area. The NBS/CBT has been invited by HUD to provide technical assistance in this U.S. representation effort and the author has been in attendance at several of the interesting, pioneering meetings.

Only those ECE governmental bodies responsible for the promulgation of national building regulations are eligible to participate in this UN project. HUD was selected to represent the U.S. in this activity because:

1. HUD is the promulgator of the Federal mobile home regulations (perhaps the only set of national mandatory building regulations in the U.S.). HUD is also the promulgator of the FHA Minimum Property Standards that are national in scope and are a form of building requirements for HUD mortgage insurance programs. 
2. HUD, as a Federal agency, satisfies the national governmental admission requirements of the United Nations.

Obviously, the decentralized nature of the U.S. building regulatory system precludes HUD from making U.S. action commitments in this harmonization project. HUD is trying to monitor the more important of the scheduled meetings involved, but recognizes that it is not empowered to speak for the State and local authorities responsible for the bulk of U.S. building regulations.

However, developments in the UN/ECE and ISO are reaching a stage where they could become useful to HUD and the new U.S. Department of Energy (DoE) especially in those areas where both have been given a regulatory mandate by Congress. These areas include:

1. Mobile home regulations, and

2. Energy conservation requirements for buildings.

In both areas the Congressional legislation involved specifically directs the promulgation of these regulations on a performance basis. This charge, of course, parallels the central theme of the UN/ECE-ISO harmonization project. Any developmental work undertaken by HUD and DoE along performance lines, in accordance with the Congressional mandate, could be designed to take advantage of this ongoing UN/ECE-ISO project. Since this project and the U.S. programs are both in the formative stage and aimed at the same goal, a U.S. input on any portion of the work involved would be welcomed by other UN/ECE participants and could make an important contribution, useful to both the developed and developing countries. Out of such a cooperative international program could come the outline of a model performancebased regulatory system that could be used by any nation wishing to have a national system possessing a built-in international compatability.

\section{A MAJOR METRICATION PLANNING AND REGULATORY ISSUE FOR THE U.S. CONSTRUCTION COMMUNITY}

The investigative phase of U.S. metrication planning has already revealed that the entire technical data base on which the construction industry operates must be rewritten in SI terms. Included among the subjects of this rewriting are all:

(a) design, process and product standards;

(b) building regulations - 1ocal, State and Federa1;

(c) test methods;

(d) quality approval and quality control procedures;

(e) other technical supportive documents such as text books, design/engineering guides, architectural details, manufacturers'catalogs and installation instructions, manufacturers' shop drawings, packing lists and bills of material, computer programs, etc.

The above list is formidable and the effort required seems truly awesome. Fortunately, the U.S. will be able to draw on the wealth of experience generated by the conversion activities of the other English-speaking countries. It is also fortunate that the construction trends associated with the worldwide movements to SI and dimensional coordination are becoming quite clear. One of the more important of these trends--the emerging development of international performance-based building regulations--is occurring just as the new National Institute of Building Sciences (NIBS) is coming on stream in the U.S. 
NIBS has been given a charge by the U.S. Congress that is strikingly similar to the UN/ECE performance-based building regulatory project. Public Law 93-383, 18/ that established NIBS, states:

"The Institute shall exercise its functions and responsibilities in four general areas, relating to building regulations, as follows:

(A) Development, promulgation and maintenance of nationally recognized performance criteria, standards and other technical provisions for maintenance of life, safety, health and public welfare suitable for adoption by building regulating jurisdictions and agencies, including test methods and other evaluative techniques relating to building systems, subsystems, components, products and materials with due regard for consumer problems.

(B) Evaluation and prequalification of existing and new building technology in accordance with subparagraph (A).

(C) Conduct of needed investigations in direct support of subparagraphs (A) and (B).

(D) Assembly, storage and dissemination of technical data and other information directly related to subparagraphs (A), (B), and (C)."

Thus, if U.S. metrication planners develop a standards conversion program that fully exploits the new universality of SI and dimensional coordination, the resulting collection of new metric standards should greatly simplify the task of NIBS. NIBS could then effectively engage in and benefit from a participatory role in the UN/ECE-ISO development of an international harmonized performance-based regulatory system.

As members of the U.S. construction community continue to seek an overview from which to most profitably plan their metrication program, the full import of a world finally in possession of a common measurement alphabet, SI, is beginning to be perceived. The United States is not just adopting a simpler, more coherent measurement system, it is joining a metric world. By this action the U.S. closes a serious communications gap and opens a new era of opportunities for meaningful technical and economic collaboration among nations.

International recognition of this global aspect of SI is evidenced by the thrust of the new standards policies established by the Helsinki Agreement--in which the U.S. was both a participant and a signatory. It is displayed as the central theme of the proposed GATT Standards Code--in whose development the U.S. has been an active participant. The thrust of the one and the theme of the other are already being put to work by alert government and industry representatives in the performance-based regulatory project of the UN/ECE-whose aims are so similar to the charge given NIBS. These SI-inspired activities, buttressed by the worldwide adoption of dimensional coordination--an original U.S. concept now internationally utilized, are clearly discernible "change-course" trends occurring in the metric building world that the U.S. is getting ready to join.

It is the convergence of these SI-inspired international activities with the beginning of the U.S. metrication planning effort and with the emergence of NIBS that raises a major issue for the U.S. construction community.

Metrication planning is a once only opportunity that involves a concentrated industry-wide attention to the conversion of its entire technical data base to SI terms. Whether to treat this mammoth operation as an internal U.S. affair, or as the entranceway into the new metric building world, becomes the issue of greatest importance to the U.S. building community.

18/The Housing and Community Act of 1974, Section 809 - National Institute of Building Sciences, Congressional Record, August 12, 1974. Information on NIBS can be obtained from 1730 Pennsylvania Avenue, NW., Washington, D.C. 20006. 
APPENDIX I

Policy Statement

\section{UNITED NATIONS}

Economic Commission for Europe

Committee on Housing, Building and Planning

Fourth Seminar on the Building Industry

London 1973 


\title{
Appendix I
}

\author{
Fourth Seminar on the Building Industry, London 1973
}

\section{Policy Statement}

The Fourth Seminar on the Building Industry of the United Nations Economic Commission for Europe (ECE) Committee on Housing, Building and Planning having met in London from 8 to 13 October 1973 to consider the need to harmonize regulations and standards in order to promote intemational trade in building materials, components and equipment as well as in constmuction machinery and know-how.

Recalling: that some 15 to 20 percent of the country's national resources are spent on the constmetion modemization, maintenance and repair of buildings and other constmution work; that the construction industry generally contributes 7 to 10 percent to the national income and employs a similar percentage of the adult working population; that construction work accounts for more than half the total investments in ECE countries; and consequently, the improved efficiency in the constmuction sector yields significant returns of society at Zarge.

Recognizing the necessity of systematically improving social conditions and the standard of living and of taking measures to contribute to these aims by improvements in the quality of building and the built environment.

Appreciating that the industrialization of the building production process has resulted in improved labour productivity and building economy, thus enabling countries to meet their building commitments within the labour and material resources available.

\section{General Conclusions}

A. States the conviction that:

1. Further economies and a better utilization of resources can be attained if industrial methods, integrating design, manufacturing and marketing, are consistently and extensively used in the production and assembly of buildings and their equipment.

2. Greater trade in building components, equipment, machinery and know-how can: considerably hasten the industrialization of the constmuction sector; contribute to an improvement in the quality of construction and the built environment; stimulate closer intemational co-operation and contacts among all countries in the region; help to adjust cyclincal variations in building demand and capacity, thus maintaining greater stability in building costs; and, in some countries, strengthen competition and check inflationary pressures emerging from the construction sector.

Concludes that:

1. Differences in the technical content of national building regulations and in national standards constitute the principal technical obstacles to greater intemational trade in building materials, components, equipment and know-how and to intermational technical co-operation in the constmuction field.

2. Differences in national regulations regarding measures to prevent accidents and occupational diseases, protection from noise and pollution, permissible loads and dimensions and safety coefficients to be applied in design constitute the principal obstacles to greater trade in building machinery and equipment. 
3. Differences in national building and safety regulations and in national standards currently in use in ECE countries do not appear to result only from variations in physical conditions (climate, seismicity) or in levels of technical and economic development but reflect national customs, materials and methods of building which constitute the basis of constmetion in its traditional forms. The use of descriptive and non-functional requirements in regulations and standards accentuates this situation.

4. Regulations and standards constitute complementary categories of requirements placed on the building industry by society. Therefore, in spite of their different character, regulations and standards should be considered together in the light of their combined effect on buildings and on the building process. It follows further that work on the establishment of regulations and standards should be co-ordinated.

5. The absence of an agreed presentation of information on building products and on adaption of this information to meet the local peculiarities of the importing country constitutes an impediment to international trade.

Notes with satisfaction that:

1. Considerable efforts have already been or are being made in most ECE countries to modernize and unify building regulations at the national level as a means of increasing efficiency in the building industry and to facilitate the introduction and wider application of industrial construction methods and new building materials.

2. Similar activities are being undertaken within the framework of sub-reaional inter-govemmental co-operation, 19/ the ultimate aim of which is to harmonize building regulations for the promotion of technical development and trade in the building component and constmetion sectors.

3. Efforts are also being made to unify safety regulations and safety provisions relating to the design and use of building machinery.

4. Intematioral standardization is gradually gaining momentum in the building field and has already produced some results. 20

Strongly emphasizes:

1. The importance of undertaking co-operation and harmonization throughout the ECE region as a whole if increased trade in building components, equipment, machinery and know-how is to be secured.

2. The importance of undertaking the harmonization of building regulations as a means of encouraging a wider application of research and new technologies in constmetion.

3. The need for close co-operation between public authorities and representatives of the industry, the professions, the investors and the users in the work on the harmonization of building regulations and standards as well as in standardization work, both at national and intemational levels.

xbly by the Council for Mutual Economic Assistance (CMEA), the Commission of the ean Communities (CEC) and the Nordic Committee on Building Regulations (NKB).

paper prepared for the Seminar by the International Organization for Standardization 
- The fact that if the fulz benefits arising from the harmonization of building regulations and standards are to be achieved, governments and intemational organizations concermed should urgently study and take measures to remove trade restrictions in the building field.

\section{'AL RESOLUTIONS AND RECOMMENDATIONS}

'esolves that:

- Concerted efforts should be made by ECE member countries to harmonize the technical content of building regulations on the basis of requirements expressed, as appropriate, in terms of function and performance of the completed building, and using, where appropriate, internationally standized scales of values. The regulations should be based on intemationally agreed terminology and verification methods and be stated, as far as possible, by reference to International Standards.

- Uniform methods of assessment, testing and certification should be established in co-operation with the ECE and other organizations concerned. This work should include consultation between countries with a view of unifying quality markings and labels and the principles of their attribution so as to obtain a complete and intermationally agreed system of quality markings for building materials, components and equipment in ECE countries.

'ecommends that:

- Uniform intemational regulations goveming safety and welfare on site should be developed. Such regulations should cover the operation and use of plant and equipment with the aim of facilitating trade in such plant and equipment and of simplifying the operation of contractors in countries other than their own.

- Govemments should actively promote the development of intemational standards for the design and production of building materials and components, machinery and equipment for production and construction. Efforts should be made by the ISO to reach agreement on the presentation of intemational standards and, where possible, to express such standards in terms of performance or function taking into account the various uses made of standards in ECE countries in respect of building design and constmuction techniques.

- Govermments should promote the application of agreed standards (preferably intemational where available) and the use of agreed quality markings or agrements in the building materials and constmuction field by prescribing as appropriate, that reference be made to such standards, markings and agréments in public contracts and in contracts benefiting from public aid. Govermments may also encourage the application and use of standards, quality markings agréments by financial incentives or by special clauses related to public financing and subsidies.

- Govermments should study the possibilities of accepting without further formalities building materials and systems which are subject to an appropriate foreign approval confirmed by a national body.

- Goverments should actively promote intemational research activities related to the development of building regulations and standards and methods of design, assessment, testing and certification. The organizations concemed should devote more attention to research in this field. 
6. Consideration should be given to the codification of methods of design in order to promote the wider use of components and the industrialization of building.

7. Promotional campaigns should be launched with a view to familiarizing building clients, designers and contractors with the advantages of using materials and components based on intemational standards and agreed quality markings. Producers of building products should be encouraged to apply agreed standards and markings, especially for products entering the international market.

8. Goverments should ensure that information on regulations, standards, directives, testing and verification procedures relating to building and building machinery be made available for reference at an officially recognized central point or national information center. Governments should also encourage a close international co-operation among the central points or national information centres. This co-operation should include the establishment of an agreed outline or framework for the presentation of regulations and standards which would permit a direct comparison between countries and facilitate harmonization efforts.

9. Measures should be taken to ensure that the knowledge and experience gained from the programe of harmonizing building regulations and standards in the ECE region be made available to other regional economic commissions for the benefit of developing countries throughout the world.

\section{SPECIFIC RESOLUTIONS AND RECOMMENDATIONS}

G. Resolves that:

1. The Working Party on the Building Industry of the ECE Committee on Housing, Building and Planning should:

(a) identify the work necessary for the harmonization of the technical content of building regulations in the ECE region;

(b) promote the essential coordination of the harmonization of such basic technical content of building regulations which are of a general interest in the region;

(c) promote co-operation among non-govermmental intermational organizations concermed with standardization and research activities related to building regulations; and

(d) review priorities and progress of intemational standardization and research activities related to regulations on building and building machinery.

This work should be undertaken in close consultation with sub-regional inter-governmental organizations and take into account studies and co-operation activities carried out by those organizations and by the ECE meetings of govermmental officials responsible for standardization policies.

H. Recommends that the following action should be taken with a view of facilitating the harmonization and unification of building regulations in the ECE region:

1. The preliminary report on systems of buizding regulations in ECE countries, prepared under the auspices of the ECE Committee on Housing, Building and Planning, should be finalized for publication in printed form in the first half of 1973. 
2. A comprehensive directory should be prepared listing competent public authorities, semi-public institutions and agencies which are responsible, centrally for a country as a whole (or for an important constituent part), for the issue of general approvals of typical drowings for structures and other building components and are also in a position to supply information concerning approved and checked typical products. A directory should also be prepared listing organizations or bodies concerned with mandatory qualification requirements of designers and supervising site engineers. The first draft of these two reference documents should be completed before the end of 1974 .

3. In 1974, an outline should be agreed internationally 21 l to serve as guidance for the systematic listing of national building regulations currently in use in the ECE countries.

4. A technical glossary should be prepared and published as soon as possible to enable ECE countries to use a common terminology and common definitions in their regulations and standards.

I. Reconmends that the following priority action should be simultaneously considered in the elaboration of a programe of work on the harmonization of building regulations.

1. Unified principles should be-developed for the specification of climatic effects (wind, snow, rain, cold, heat, damp, etc.) and seismic effects, respectively, on buildings and installations. On the basis of this work, climatic and seismic zones should be determined for Europe and uniform regulations established for each zone in respect of climatic and seismic effects.

2. Unified principles should be developed for expressing requirements in regulations in performance or functional terms related to uniform methods of control and supplemented by examples of design deemed to satisfy such requirements.

3. The human requirements for the internal climate in buildings--especially dwellings and working premises--from the standpoint of health and hygiene should be studied further as a preparatory stage for the harmonization of building regulations in this field.

4. Uniform standards and related regulations should be established for fire protection and means of escape in the event of fire. Intemationally agreed principles should be applied to the classification of fire resistance of building components and surfaces.

5. Uniform methods of calculation should be established for the design of building structures and safety devices. The design loads must be co-ordinated with the safety requirements applied, making use wherever possible of international standards.

J. Recommends that ISO should, taking into account what has been done by other organizations, undertake the following action in the building field:

1. Priority should be given to reaching agreement on common terminology, units of measurement and methodology used in designs and calculations. Action should be taken to ensure the rapid introduction of the SI system of units in intemational building standards to enable the wider adoption at the intemational level of the SI system and its derivatives.

2I Within the framework of the activities of the Working Party on the Building Industry. 
2. A uniform and fully developed system of dimensional co-ordination in building should be adopted. It should include the establishment of uniform systems for the positioning of components, and for joints, tolerances and fits in constmuction, taking into account the likelihood of such systems being associated with similar systems used in other industries, in order that a precise fit between building components can be assured in industries applying different levels of precision.

3. High priority should be given to the establishment of such intermational standards to which reference can be made in building regulations.

4. In measures taken to standardize plant and machinery, attention should be paid to establishing uniformity on items, such as tests for machinery, structural calculations, permissible levels of pollution (noise and fumes), operating controls (steering mechanisms, calibration of weighing machinery), calculations affecting permissible loads and working outputs.

\section{DEFINITIONS}

-- Building regulations are documents containing requirements for buildings laid down by an official body (Parliament, the govermment or the responsible authority) to ensure the safety, hygiene, stability and level of comenity compatible with environmental and social requirements during the constmction and throughout the lifetime of the building.

-- Building standards are documents chiefly stating the essential properties of buildings, building components and building products, including their dimensions, characteristics and performance. Frequently, standards also contain information about how these properties can be verified. In general, building standards are related to building regulations by virtue of the fact that the properties stated satisfy safety requirements in the regulations, and it is for this reason that reference is often made to standards in regulations. 
APPENDIX II

Prominent International Organizations Related to the UN/ECE-ISO Harmonization of Building Regulations Project는

22/Much of the descriptive material in Appendix II has been distilled from information contained in the 1977 Yearbook of International Organizations, published by the Union of International Associations, 1 rue aux Laines, 100 Brussels, Belgium. 
Descriptions of International Organizations Important in the Metric Building World

CEB - European Committee for Concrete

6 rue Lauriston

75116 Paris, France

The CEB was founded in 1953 and consists of organizations and individuals in Austria, Belgium, Brazil, Bulgaria, Canada, Cuba, Czechoslovakia, Denmark, Finland, France, Democratic Republic of Germany, Federal Republic of Germany, Greece, Guatemala, Hungary, Iran, Israel, Italy, Japan, Lebanon, Luxembourg, Mexico, the Netherlands, Norway, Poland, Portugal, Romania, Spain, Sweden, Switzerland, Turkey, United Kingdom, Union of Soviet Socialist Republics, Venezuela and Yugoslavia.

The objectives of the CEB are:

1. To synthesize existing scientific knowledge and coordinate the programs and results of research carried out in member countries.

2. To produce new basic criteria and data for structural safety.

3. To evolve practical methods for the structural design and technical-economic optimization of structures.

4. To develop unified Recommendations and in particular a unified standard system of international codes for the planning, design and construction of concrete structures relevant to the various technical applications of concrete in practice.

5. To publish Guide Manuals for Design and Technology and to develop practical methods for the application of the International Recommendations, with a view to technical-economic improvement and greater industrialization of construction methods.

The CEB intends to strive for technical participation in all activities aimed at international harmonization and unification of Civil Engineering Codes of Practice in particular with the EEC, the CMEA, the UN/ECE, the ISO, CEN, NKB and other international Civil Engineering organizations such as FIP, RILEM and the CIB. 
Utrechtseweg 310 ,

Arnhem

The Netherlands

The CEE was found in 1946. Its membership consists of national organizations in 23 countries: Australia*, Austria, Belgium, Bulgaria, Canada*, Czechoslovakia, Denmark, Finland, France, Federal Republic of Germany, Greece, Hong Kong*, Hungary, Iceland*, India*, Ireland, Italy, Japan*, the Netherlands, Norway, Poland, Portugal, Spain, South Africa*, Sweden, Switzerland, the United Kingdom, United States*, Union of Soviet Socialist Republics and Yugoslavia.

The aims of the CEE are to define the conditions with which electrical equipment in common use should comply in order to protect the public against risks which may rasult from using equipment of poor quality, particularly from the point of view of danger to life and of fire; bring about as much uniformity as possible in the national regulations in force in the member countries.

The CEE issues specifications for different types of electrical equipment. It has established a Certification Body which administers a scheme of approval. This body has introduced a CEE Mark to give the user a simple and definite means of recognizing equipment which conforms to CEE specifications.

*Denotes Observer Members. 


\section{5 , Boulevard de $l^{\prime}$ Empereur}

B-1000

Brussels, Belgium

CEN was founded in 1961 and its present title was adopted in 1971. Its members consist of the national standards bodies of Austria, Belgium, Denmark, Finland, France, Federal Republic of Germany, Ireland, Italy, the Netherlands, Norway, Portugal, Spain, Sweden, Switzerland and the United Kingdom.

The aim of CEN is to promote the development of trade and exchange of services through the elimination of technical obstacles thereto by the establishment of European Standards. These are to be adopted without deviation as national standards. They are designed for use by the Common Market Commission and other intergovernmental organizations as documents to which reference can be made in directives and similar instruments. At the present time there are 42 such European Standards (EN), 40 of which have been developed since 1974. Forty-six more are in the voting process.

CEN also provides support for the world standardization activities of ISO and IEC and works toward the uniform application of such standards in Europe.

The parallel (but separate) organization to CEN in the electrotechnical field is CENELEC European Committee for Electrotechnical Standardization. It was founded in 1973 as a result of a merger between the European Committee for the Coordination of Electrical Standards (CENLCOM) and the European Standards Coordinating Committee (CENEL). CEN and CENELEC operate on a cooperative basis.

A separate organization, CENCER, has been established to provide certification services to CEN standards. It and CENELEC are both located at the same address as CEN. The documentation for CENCER services have been completed and already the conclusion of a reference to CENCER certification is seen in a draft EEC Directive for scaffolding components in conformity with draft standard EN 74. 
704 Weena

P.0. Box 20704

Rotterdam-3, Netherlands

The CIB was founded in 1953 as a result of a Conference on Building Research convened by the United Nations' Economic Commission for Europe. It consists of public and industrial organizations in the following countries: Australia, Austria, Argentina, Bangladesh, Belgium, Brazil, Bulgaria, Caṇada, China, Colombia, Cuba, Czechoslovákia, Denmark, Ethiopia, Egypt, Finland, France, Democratic Republic of Germany, Federal Republic of Germany, Ghana, Greece, Hungary, India, Indonesia, Iran, Ireland, Israel, Italy, Ivory Coast. Japan, Luxembourg, Mexico, the Netherlands, New Zealand, Norway, Pakistan, Poland, Portugal, Romania, Sudan, South Korea, Spain, Sweden, Switzerland, Tanzania, Togo, United Kingdom, United States, Union of Soviet Socialist Republics, Venezuela, and Yugoslavia.

The aims of the CIB are to encourage, facilitate and develop international cooperation in building research studies and documentation covering not only technical but also the social and economic aspects of building. It seeks to find out how far this international collaboration can be extended to ensure a better use of highly specialized qualified manpower and very complex and costly equipment. The CIB endeavors to bring, at an international level, the results of research to the notice of those who apply and use them in daily practice.

Essentially membership in CIB is institutional, however, individual membership for experts unable to easily establish liaison through a member institution is possible. CIB does not have "member countries" nor is CIB institutional membership limited to one institution per country. The "public full members" are the large public building research organizations. The large industrial bodies involved in building research are the "industrial full members." Such members are engaged in comprehensive research programs and they have an adequate and qualified staff of reseachers. "Associate members" are institutions whose building research is limited to specific fields of inquiry. "Unattached members" of CIB are individual specialists not having an institutional liaison with CIB.

International research and study projects are undertaken by Working Commissions or ad hoc groups of competent specialists from different national institutes working in the field. Many of these Commissions provide the data used by ISO committees in the development of international standards. This work is looked upon as a "prestandardization" activity by ISO and CIB. CIB Working Commission $W-24$ provides the prestandardization research data for the dimensional coordination activities of ISO/TC 59. W-60 fulfills a similar role for the performance standards activities of ISO Technical Committee 59 (TC 59), and W-62 provides similar data on plumbing research.

Because of this close working relationship to building standardization, the CIB occupies a special consultative position with the UN/ECE and with ISO. The CIB has accepted the ISO invitation to become a member of the ISO building standards management group - Technical Division 3 (TD 3). 
CMEA - Council for Mutual Economic Assistance

56, Kolinina Prospect

Moscow G205, USSR

The CMEA is an international consortium founded in 1949 whose members are:

The Peoples' Republic of Bulgaria

The Hungarian Peoples' Republic

The German Democratic Republic

The Republic of Cuba

The Mongolian Peoples' Republic

The Polish Peoples' Republic

The Romanian Peoples' Republic

The Union of Soviet Socialist Republics

The Czechoslovak Socialist Republics

Yugoslavia participates in CMEA in matters of mutual interest. The Democratic Republic of Vietnam and the Peoples' Democratic Republic of Korea are observers. Cooperative agreements have been established between CMEA and Finland, Iraq and Mexico.

Its purpose is to "insure further fulfillment of the tasks of a comprehensive program to extend and improve cooperation and the development of socialist economic integration." (Statute of CMEA Standard, approved by the 28th CMEA Session, Sofia, June 21, 1974.)

One of the ways this is to be accomplished is through the mechanism of commonly developed standards for products traded between CMEA nations, and through other standardization projects of a general technical nature. These standards include:

- classifications, terminology and designations

- types and sizes

- safety in the workplace

- test methods

- weights and measures

- marking, packing, transportation, storage

- technological processes

Proposals for annual plans for CMEA standards development are drafted by member country delegations in the CMEA Standing Commission on Standardization. The standards are drafted either within the framework of this Commission or through standing intersector commissions for articles covered by their assigned scopes.

Once developed, CMEA standards become compulsory in contractural and legal relations in scientific, economic and technical cooperation among the signatory nations.

The CMEA is active in the UN/ECE project on the harmonization of building regulations and in the building standards activities of the ISO (in addition to coordination and cooperation activities in other subject areas). It provides an international forum in the controlled market countries somewhat similar to that. provided by the European Economic Community (EEC).

In addition to the Standing Commission on Standardization, other Commission scopes cover: statistics, foreign trade, currency, electric power, use of atomic energy, coal, oil and gas, chemicals, metallurgy, machine tools, electronics, food, agriculture, construction, transport, geology, communications, public health and civil aviation. 
200 rue de la Loi

B-1049

Brussels, Belgium

The EEC was established in 1958. It is an amalgamation of institutions in the first step towards the setting up of a single European Commuity governed by a single treaty. It is often referred to as "the Common Market." The aims of the EEC are to promote a harmonious development of economic activities throughout the community.

Member countries of the EEC are: Belgium, Denmark, France, West Germany, Ireland, Italy, Luxembourg, the Netherlands and the United Kingdom.

Decisions are taken by the Commission and the Council of Ministers which, following the institutional merger in 1967 of the three large European organizations (ECSC - Consultative Committee of the Coal and Steel Community, EURATOM - European Community of Atomic Energy, and the EEC), are now common to all three.

The Commission is the permanent body for representing the Community. It is directed by 13 members appointed for four years. The United Kingdom, France, West Germany and Italy each propose two members and the others one member each. Although the Commissioners are appointed by the nine governments jointly they may not seek or accept instructions from any government or other body. They take their decisions by majority vote and are collectively responsible to the community as a whole.

The Council of Ministers, composed of members of the governments of Member States, is the only Commity institution whose members directly represent the national governments. It is composed of nine members, one from each of the member countries.

Ninety associated or other countries have diplomatic missions accredited to the Community in Brussels. The EEC has become one of the world's largest economic units. Its unified market of over 250 million people accounts for about one-fifth of world trade, leaving aside the trade among the nine member states themselves. The value of goods and services generated in the nine countries in 1976 amounted to over $\$ 1,400$ billion, second only to the U.S. Some 13,000 people are employed by EEC institutions.

At a Paris summit conference in 1972 the Community's leaders resolved to form a broader and deeper European union by the end of this decade. Included in the Paris agreement were a series of policy objectives that included a full economic and monetary union by 1980, possibly with a common currency.

The EEC Council has issued two basic directives (October 18, 1971 and July 27, 1976) in addition to a number of corollary directives, specifying that the Member States are to require by April 21, 1978 the use of SI metric units in all commercial transactions. A more detailed description of these directives and their implementation appears in a U.S. Department of Commerce publication, "Metric Laws and Practices in International Trade--A Handbook for U.S. Exporters." This is available from the Superintendent of Documents, U.S. Government Printing Office, Washington, D.C. 20402, \$1.45 per copy. 
EFTA - European Free Trade Association

9-11 rue de Varembe

1211 Geneva, Switzerland

EFTA was established in 1960. It originally consisted of nine countries: Austria, Finland (Associate Member), Ireland, Norway, Portugal, Sweden, Switzerland, the United Kingdom and Denmark. The last two left the EFTA in 1972 on becoming members of the EEC.

The aims of EFTA are to promote in the area of the Association and in each member country a sustained expansion of economic activities; increased productivity, financial stability, and continuous improvement in the standard of living; insure that trade between Member States takes place in conditions of fair competition; avoid significant disparity between member countries in the production and conditions of supply of raw materials; and contribute to the harmonious development and expansion of world trade and to the progressive removal of barriers to it.

By the end of 1966 import duties on industrial goods traded within EFTA, except for a very few items were abolished. Finland abolished its import duties one year later. 
The EOQC was founded in 1956 following a general conference on quality control organized by the European Productivity Agency. Full members consist of accredited national quality control organizations in each of the 22 European countries. Institutional and Individual Associated memberships are open to individuals and organizations in non-full member countries.

The aims of the EOQC are to initiate, disseminate, and improve by all appropriate means, the use and application of the techniques and philosophy of quality control. The intent is to improve the quality and reliability of goods and services by organizing congresses, seminars, committees and courses and by exchanging documentation and instructional aids.

The EOQC has specialized committees and sections for individual industries. The EOQC has shown a special interest in the building regulatory harmonization work of the UN/ECE. 


\section{EUROPREFAB - European Organization for the Promotion of Prefabrication and Other}

Industrialized Building Methods

82 New Cavendish Street

London WIM $8 \mathrm{AD}$, England

The EUROPREFAB was formed in 1965 as a Federation of European Associations concerned with industrialized building. In 1976 there were 14 national members: Austria, Czechoslovakia, Denmark, France, Federal Republic of Germany, Hungary, Italy, the Netherlands, Norway, Spain, Sweden, Switzerland, United Kingdom and Yugoslavia.

The purpose of EUROPREFAB is to promote an exchange of information about industrialized building. Liaison is one of its important activities. It maintains contact with the EEC, ISO, CEN and especially the UN/ECE Committee on Housing, Building and Planning. Emphasis has been given to the need for industrialization in relation to plans for unifying construction markets in the EEC. The work being done by EUROPREFAB has the same aims as the UN/ECE work on the harmonization of national building regulations and building standards. 
Waxham Springs

Slough SL3 6PL

England

The FIP was founded in 1952. Its aims are to act as a permanent link between member groups; promote the formation of groups for the advancement of prestressing in all countries; centralize all scientific, technical information and problem-solving connected with prestressing. Its members consist of 47 associations in 45 countries.

The FIP is a member of a liaison committee formed in the field of concrete by the International Association for Bridge and Structural Engineering (IABSE), the International Association for Shell Structures (IASS), Comite eu de Beton (CEB), International Union of Testing and Research Laboratories for Materials and Structures (RILEM) and the International Council for Building Research, Studies and Documentation (CIB).

The FIP has evidenced considerable interest in the building regulatory harmonization project of the UN/ECE-ISO. 
The IABSE was founded in 1929 in Zurich. Its aims are to promote international cooperation among scientists, engineers and manufacturers in the field of bridge and construction engineering, regardless of the principal materials involved. Membership consists of delegates from each national group selected on a sliding scale depending on the number of such groups. The IABSE has over 2,600 individuals or institutional members located in 57 countries. Four hundred and twenty of these are from the Americas (including the USA) while 1,700 are from Europe. 
IAEE - International Association for Earthquake Engineering

c/o International Institute of Seismology and Earthquake Engineering (IISEE)

Building Research Institute

3-chome, Hyakunin-cho

Shinjuku-ku, Tokyo, JAPAN

The IAEE was founded in 1963 as an outcome of a meeting arranged by Japan and the IISEE, an organization established jointly by the United Nations and Japan.

Its aims are to promote international cooperation among scientists and engineers in the field of earthquake engineering, through an interchange of knowledge, ideas and results of research and practical experiences, by holding world conferences.

Its membership consists of national committees established in 31 countries: Argentina, Australia, Bulgaria, Canada, Chile, El Salvador, Ethiopia, France, Democratic Republic of Germany, Federal Republic of Germany, Ghana, Greece, India, Indonesia, Italy, Iran, Japan, Mexico, New Zealand, Nicaraugua, Peru, Phillipines, Portugal, Spain, Turkey, United Kingdom, United States, Union of Soviet Socialist Republics, Venezuela, and Yugoslavia. 
IASS - International Association of Shell and Spatial Structures

c/o Asociacion Internacional de Estructuras Laminares y

Espaciales

Alfonso XII

3 Madrid, Spain

The IASS was founded in 1959. Its aims are to assist in the development of the technology of constructing shells for three dimensional continuous or discontinuous structures, whose thickness is small compared to their other two dimensions.

The IASS has over 700 individual members and 49 collective members. 
1 , rue de Varembe

1211 Geneva, Switzerland

The IEC was founded in 1906 in London. The IEC is the international standards organization in the electrical field. Its purpose is to facilitate the coordination and unification of national electrical standards. It is considered the affiliate of the ISo in the electrical standards field.

There are over 70 established technical committees in IEC that hold over 100 meetings per year. Members of the IEC are national committees composed of representatives of technical and scientific organizations dealing with electrical standardization on the national level. One such national committee from each of the 42 participating countries comprises the membership of the IEC.

The IEC issues consensus-based international standards intended to assist in the harmonizing of national standards. Over 1000 IEC standards are now in existence.

The IEC, like the ISO, is viewed as a major standardization resource by the participants in the UN/ECE project on the harmonization of building regulations. 
The ILO was established in 1919 as an autonomous body associated with the old League of Nations. It became a Specialized Agency of the United Nations in its own field of competence. Some 122 nations are members of the ILO's International Labor Conference, the main governing body. National delegations are composed of two government delegates, one worker and one employer delegate.

The aims of the ILO are to raise working and living standards throughout the world. In so doing, it seeks to eliminate social injustices, with their consequence in unrest, considered to be a cause of war. One of the primary functions of the ILO is to help improve the social and economic well being of working people everywhere by building up a code of international labor standards. These take the form of Conventions and Recommendations relating to basic human rights, employment and training policy, conditions of work, social security, industrial relations and a variety of other social matters.

The ILO is participating in the UN/ECE-ISO project on the harmonization of national building regulations. 
The ISO was founded in 1946 to follow up the work of the International Federation of National Standardizing Associations and the United Nations' Standards Coordinating Committee. Its older counterpart in the electrical field is the International Electrotechnical Commission (IEC).

The work of ISO is aimed at worldwide agreement on International Standards with a view to the expansion of trade, the improvement of quality, the increase of productivity and the lowering of costs.

The ISO is composed of the principal national standards bodies of 82 countries. The technical work of ISO is carried out by 1629 technical bodies (152 technical committees, 492 subcommittees and 985 working groups). Three hundred and fifteen international organizations have been granted liaison status with ISO technical committees. In a year more than 10,000 working documents are circulated to participants. Each year there are some 800 ISO technical meetings held in some 40 countries and attended by more than 20,000 delegates. At the end of April 1977, 3300 ISO standards were available; 1500 draft standards and 1750 draft proposals were registered with the ISO Central Secretariat. More than half of the existing ISO standards have been published or revised in the past three years.

The USA member body of ISO is the American National Standards Institute (ANSI). More information on ISO is contained in the body of this report.

There are many ISO Technical Committees (TC) developing standards related to construction. The following are considered those most directly related:

Technical Committee

TC 5

TC 10

TC 11

TC 17

TC 21

TC 35

TC 43

TC 55

TC 59

TC 71

TC 74

TC 77

TC 80

TC 86

TC 89

TC 92

TC 98

TC 99

TC 105

TC 116

TC 138

TC 139

TC 151

TC 152

TC 160

TC 162

TC 163

TC 165

TC 167
Subject

Metal Pipes and Fittings

Technical Drawings

Boilers and Pressure Vessels

Steel

Equipment for Fire Protection

Paints and Varnishes

Acoustics

Sawn Timber and Sawlogs

Building Construction

Concrete

Cement and Lime

Products in Fibre Reinforced Cement

Safety Colors and Signs

Refrigeration

Fibre Building Boards

Fire Tests

Bases for Design of Structures

Semi-Manufacturers of Timber

Steel Wire Ropes

Space Heating Appliances

Plastic Pipes, Fittings and Valves

Plywood

Particle Boards

Gypsum

Glass in Building

Doors and Windows

Thermal Insulation

Timber Structures

Steel and Aluminum Structures
Secretariat

Switzerland

Germany

United States

United Kingdom

United Kingdom

Netherlands

Denmark

Soviet Union

France

Austria

Belgium

Switzerland

Netherlands

Soviet Union

Germany

United Kingdom

Poland

Rumania

United Kingdom

United Kingdom

Netherlands

Germany

Germany

France

United Kingdom

Norway

Sweden

Denmark

Norway 
Examples of the more important (from a metric dimensioning viewpoint) of the standards these committees have produced are:

Technical Committee

Subject

Total Standards Produced

TC 55

Sawn Timber and Sawlogs

$\underline{23}$

ISO 737-1975 Coniferous sawn timber--Sizes--Methods of measurement

ISO/R 738-1968 Coniferous sawn timber--Sizes-Tolerances and shrinkage

ISO 3179-1975 Coniferous sawn timber--Nominal dimensions

TC 89

Fibre Building Boards

$\underline{11}$

ISO 2695-1976 Fibre building boards -- Hard and medium boards for general purposes -- Quality specifications -- Appearance, shape and dimensional tolerances

TC 98

Bases for Design of Structures

ISO 2633-1974 Determination of imposed floor loads in production buildings and warehouses

ISO 4356-1977 Bases for design of structures--Deformation of buildings at the serviceability limit states

TC 139

Plywood

ISO 1097-1975 P1ywood--Measurement of dimensions of panels 
IUA - International Union of Architects

1 , rue d'ulm

75005 Paris, France

The IUA was founded in 1948. Its aims are to link on a democratic basis, architects from all over the world; strengthen friendly, intellectual, artistic, and professional contacts between architects of all countries; develop progressive ideas in the field of architecture and town planning.

The IUA has shown a particular interest in the UN/ECE-ISO activities pertaining to the development and use of performance standards in the international harmonization of national building regulations.

The IUA has 67 national and regional sections totaling 160,000 architects in 77 countries. 
NCM - Nordic Council of Ministers

P. 0. Box 1477, Vika

$\mathrm{N}-0 \mathrm{slo}, 1$, Norway

The Nordic Council of Ministers is a five nation consortium consisting of Iceland, Norway, Sweden, Denmark and Finland.

It was established in 1971 and the permanent secretariat was established in 1973. It is composed of the Ministers of State concerned with Nordic cooperation. The Presidency is assumed by the Minister in whose country the next session of the Nordic Council will take place.

Its aim is to examine questions of Nordic cooperation.

The Secretariat comprises the following divisions: economic coordination, environment protection, transport, and communication. Draft Programs provide for the establishment of a Nordic Fund for Technology and Development, and a new agency to deal with the testing and control of materials (Nordtest). 
The countries participating in the NKB are Denmark, Finland, Iceland, Norway and Sweden.

The object of the work of NKB is to coordinate building regulations in the five countries. The committee is assisted by a techncial secretariat provided by Denmark. The main committee establishes work programs and, through the agency of working groups, drafts of common regulations are prepared. Since 1970 the aim has been to put forward proposals for common regulations instead of merely guidelines for national regulations, as was formerly the case. To the extent feasible, these common regulations are developed in performance terms.

NKB activities have resulted in a great deal of Nordic uniformity especially in the areas of heat insulation, sound insulation, fire protection, water installations and elevators. Altogether some 70 guidelines, reports, etc., have been prepared.

The NKB is supportive of the UN/ECE project on the harmonization of building regulations and of the building standards activities of the ISO. 


\section{RI - Rehabilitation International}

122 E. 23rd Street

New York, New York 10010

RI was founded in 1922 under sponsorship of the Rotary International.

One of the aims of RI is to encourage creation of national voluntary organizations with programs to aid the disabled. RI has proclaimed the 1970's as the Decade of Rehabilitation, a global program designed to mobilize international resources in the service of the disabled.

TC 59/WG 1, dealing with international building standards for the handicapped, has initiated a cooperative approach with RI. 


\author{
RILEM - International Union of Testing and Research Laboratories for Materials \\ and Structures \\ 12 rue Brancion \\ 75737 Paris Cedex 15 France
}

RILEM was founded in 1947. At the present time it has a membership consisting of 250 building research laboratories and 550 individuals located in 75 countries.

RILEM constitutes a medium of exchange and the communication of experience, essentially the experience gained by the study of materials and building elements, by observation of works, by tests in the laboratory and in situ, and by research.

RILEM conducts research on the properties of construction materials, and develops test methods through the use of some 24 technical commissions and their associated working parties. It conducts colloquia and symposia; and participates in the exchange of scientific publications.

RILEM is a key research element in the UN/ECE project on the harmonization of building regulations and is a member of the Building/Construction Technical Division 3 (TD 3) of the ISO. The work of RILEM in the area of performance requirements and especially its collaborative test method development capabilities will be needed in the UN/ECE-ISO performance-based harmonization project.

In a UN/ECE report of a meeting in Geneva June 21, 1976, it was stated that:

"RILEM activities include, amongst others, the production of methods of test and measurement which was recognized to be a contribution to ISO and other standardization work on international test methods. There seemed to be a good possibility of recommending the harmonization of methods of test, assessment and measurement, if necessary in advance of individual product

standardization. Indeed, standards setting levels of requirement and property would be of little use without associated methods of test, whereas standard methods of test would be immediately useful as a factor in the mutual recognition of test reports without necessarily awaiting international agreements as to requirement and performance levels. In accepting this argument, the meeting indicated that perhaps even more use could be made of the valuable studies-in-depth which were a continuing feature of RILEM work."

The active RILEM committees can be classified as follows:

- specific materials or categories of materials

- research on characteristics common to building materials

- influence of media (attack, protection)

- structure, building components, load effects

- building physics

- problems of construction

- testing equipment and test methods

\section{1 comittees}

3 committees

4 comittees

5 comittees

2 committees

2 committees

3 committees 
UEA - European Union of Agrement

4, ave. du Recteur Poincare

Paris 16e, France

The UEA was established in 1960 as a logical outgrowth of the success achieved with national Agrement programs in the participating countries. Presently, the UEA membership consists of the national Agreinent institutes in Austria, Belgium, France, Federal Republic of Germany, Italy, the Netherlands, Portugal, Spain, and the United Kingdom.

The UEA is an association of national organizations responsible for assessing and sometimes certifying new products, old products used in new ways, and other innovations in building. The UEA issues Rules (formerly called Common Directives) by which products tested for approval on a national basis might be accepted in other member countries without recourse to further assessment or test. In so far as the Agrement certificates issued by each national member body of the UEA reflect compliance with building regulations, so Rules reflect a measure of regulatory requirements of all member countries of the Union. However, it should be noted that the primary objectives of national Agrement operations are to facilitate approvals for insurance and procurement requirements (public and private) and generally to support marketing and sales initiatives of the manufacturers.

In the main, initial applications are made by individual manufacturers or manufacturing trade associations, but sometimes procurement sectors (usually public offices) will commission national Agrement organizations to study and stipulate performance requirements for certain groups of products needed for specific purchasing plans. In this connection, Agrement systems pay special attention to the problems of performance-in-use and durability.

A regime of studies, assessments and tests is designed for each product or group of products. These regimes in turn become the subject of discussion and eventual agreement among UEA members for the purpose of enacting UEA Rules. While the UEA does not have its own exclusive mark or label, each of the participating organizations have such marks that are recognized nationally. Feedback from Agrement experiences, reports of performance of certified products, etc., goes to support the preparation of national and international standards in the transition from innovation to traditional.

The UEA has shown a great interest in the UN/ECE-ISO project on the harmonization of building regulations, a subject with which they have had considerable experience.

More information on the UEA and its relation to the UN/ECE-ISO projects is contained in the body of this report. 
UN/ECE - United Nations Economic Commission for Europe

Palace of Nations

CH-1211 Geneva, Switzerland

The UN/ECE was established in 1947 as one of the five regional economic commissions of the United Nations. Membership is held by the Government of 35 countries: Albania, Austria, Belgium, Bulgaria, Byelorussia, Canada, Cyprus, Czechoslovakia, Denmark, Finland, France, Democratic Republic of Germany, Federal Republic of Germany, Greece, Hungary, Iceland, Ireland, Italy, Luxembourg, Malta, the Netherlands, Norway, Poland, Portugal, Romania, Spain, Sweden, Switzerland, Turkey, Ukrania, United Kingdom, United States, Union of Soviet Socialist Republics, Yugoslavia.

The Commission operates through an annual plenary session and through meetings of its Subsidiary Bodies dealing with specific sectors of the economy. The Committee on Housing, Building and Planning ( $\mathrm{HBP}$ ) and its Working Party on the Building Industry (WP 2) -- the sponsor of the project on the harmonization of building regulations -- are two of several such Subidiary Bodies.

The activities of the UN/ECE cover such main fields as the development of trade, industrial cooperation and standardization, science and technology; economic projection and planning; environmental problems; energy; inland transport; housing, building and planning; water problems; timber and statistics.

Through the unique mechanism of tbe UN/ECE, governmental bodies are able to develop and lend weight to such international objectives as the harmonization of national building regulations and to enlist the cooperation of such nongovernmental institutions as the Iso, the CIB, RILEM, the CEB, etc. Thus, the Working Party on the Building Industry does not usually engage in detailed technical work but establishes goals, and priorities and provides coordination for the work of other organizations. It tries to provide policy guidance for these organizations and to the national public authorities in their national regulatory activities, so that the international harmonization activities are given public support and the widest possible application exposure.

More information on the UN/ECE Working Party on the Building Industry is contained in the body of this report. 
The WHO was established in 1946. Its Constitution was signed by 61 countries, 51 of whom were members of the United Nations (UN). The Pan American Sanitary Bureau (525 23rd Street, Washington, D.C.) has acted as a wHO Regional office since 1949. All countries who are members of the UN may become members of WHO by accepting its Constitution. One hundred and forty-one nations belong to the WHO, a specialized agency of the United Nations.

Article one of the Constitution states: "The objective of WHO shall be the attainment by all people of the highest possible level of health." Consequently, a wide range of functions dissolves upon it including:

(a) furnishing technical assistance;

(b) promoting, in cooperation with other specialized agencies where necessary, improvement of nutrition, housing, sanitation, recreation, economic or working conditions, and other aspects of environmental hygiene;

(c) promuting cooperation among scientific and professional groups which contribute to the advancement of health.

The WHO is looked upon as a valuable technical resource by the participants in the UN/ECE-ISO project on the harmonization of national building regulations. 
NBS-114A (REV. 7-73)

\begin{tabular}{|c|c|c|c|}
\hline $\begin{array}{l}\text { J.S. DEPT. OF COMM. } \\
\text { BIBLIOGRAPHIC DATA } \\
\text { SHEET }\end{array}$ & $\begin{array}{l}\text { 1. PUBL_IC.ATTON OR REPORT NO. } \\
\text { NBS TN-976 }\end{array}$ & $\begin{array}{l}\text { 2. Gov't Accession } \\
\text { No. }\end{array}$ & 3. Recipient's Accession No. \\
\hline \multicolumn{3}{|l|}{ 4. T:TLE AND SUBTITLE } & $\begin{array}{l}\text { 5. Publication Date } \\
\text { June } 1978\end{array}$ \\
\hline \multicolumn{3}{|c|}{$\begin{array}{l}\text { International Trends and Developments of Importance to } \\
\text { the Metrication Plans of the U.S. Construction Community. }\end{array}$} & 6. Performing Organization Cude \\
\hline \multicolumn{3}{|c|}{$\begin{array}{l}\text { 7. AUTHOR(S) } \\
\text { Charles T. Mahaffey }\end{array}$} & 8. Performing Organ. Report No. \\
\hline \multirow{2}{*}{\multicolumn{3}{|c|}{$\begin{array}{l}\text { 9. PERFORMING ORGANIZATION NAME AND ADDRESS } \\
\text { NATIONAL BUREAU OF STANDARDS } \\
\text { DEPARTMENT OF COMMERCE } \\
\text { WASHINGTON, D.C. } 20234\end{array}$}} & $\begin{array}{l}\text { 10. Project/Task/Work Unit No. } \\
4641136\end{array}$ \\
\hline & & & 11. Contract/Grant No. \\
\hline \multirow{2}{*}{\multicolumn{3}{|c|}{ 12. Sponsoring Organization Name and Complete Address (Street, City, State, ZIP) }} & $\begin{array}{l}\text { 13. Type of Report \& Period } \\
\text { Covered } \\
\text { Final }\end{array}$ \\
\hline & & & 14. Sponsoring Agency Code \\
\hline
\end{tabular}

15. SUPPIEMENTARY NOTES

16. ABSTRACT (A 200-word or less factual summary of most significant in formation. If document includes a significant bibliography or literature survey, mention it here.) In 1974 the National Bureau of Standards' Center for Building Technology began an investigation of international developments in the construction field seeking to identify those of importance to U.S. metrication planning. This report identifies and describes a group of related developments selected on the basis of their importance and potential impact on the metric future of the U.S. construction community. The purpose of the report is not to discuss the merits of going metric, but rather to display the trends and developments in the metric building world that the U.S. is preparing to join.

The report suggests that many nations, recognizing unique opportunities in a world that will soon have a common measurement system, have already begun to capitalize on the global adoption of SI--the International System of Units. The report describes the extensive efforts underway to reduce obstacles to trade caused by incompatible national regulations, standards, and certification to standards. It describes the trade implications of the Helsinki international agreements reached at the Helsinki meeting of the Conference on Security and Cooperation in Europe and being advanced in the proposed Standards Code developed by the negotiators involved in the General Agreement on Tariffs and Trade (GATT). It describes the changes in the marketplace for building components brought about by the worldwide adoption of the international standard dimensioning module of $100 \mathrm{~mm}$. It describes the launching and the status of the United Nations project aimed at the international harmonization of national building regulations; the involvement and reorganization of the building standards activity of the International Organization for Standardization 17. KEY WORDS (six to twelve entries; alphabetical order; capitalize only the first letter of the first key word unless a proper page) name; separated by semicolons)

International building performance standards; internationally harmonized building regulations; metrication impact on construction

18. AVAILABILITY $\sqrt{x}$ Unlimited

For Official Distribution. Do Not Release to NTIS

Order From Sup. of Doc., U.S. Government Printing Office

Washington, D.C. 20402 , SD Stock No. SNO0 3-003-

Order From National Technical Information Service (NTIS) Springfield, Virginia 22151

\begin{tabular}{|l|c|}
\hline $\begin{array}{l}\text { 19. SECURITY CLASS } \\
\text { (THIS REPURT) }\end{array}$ & 72 \\
UNCL ASSIFIED & 21. NO. OF PAGES \\
\hline $\begin{array}{l}\text { 20. SECURITY CLASS } \\
\text { (THIS PAGE) } \\
\text { UNCLASSIFIED }\end{array}$ & 22. Price \\
\hline
\end{tabular}


NBS-114A (Continued)

ABSTRACT

(ISO); the significance of the international evaluation mechanisms developed by the European Union of Agrement; and, the initiation of international performance standards developed through ISO Technical Committee 59 - Building Construction. All of which should be of special interest to those concerned with the development of a remarkably similar program assigned to the National Institute of Building Sciences (NIBS).

$\mathrm{U}: \mathrm{S}$. metric conversion plans could be designed to take advantage of the opportunities uniquely associated with an SI world or they could treat metrication simply as the adoption of a more modern U.S. measurement system. The report identifies this choice as a major metrication issue for the U.S. construction community. For this reason, the report should be of interest to members of the American National Metric Council and of the U.S. Metric Board.

The appendix to this report contains a brief description of 22 international organizations considered to be of future significance to the U.S. as it joins the SI metric building world. 


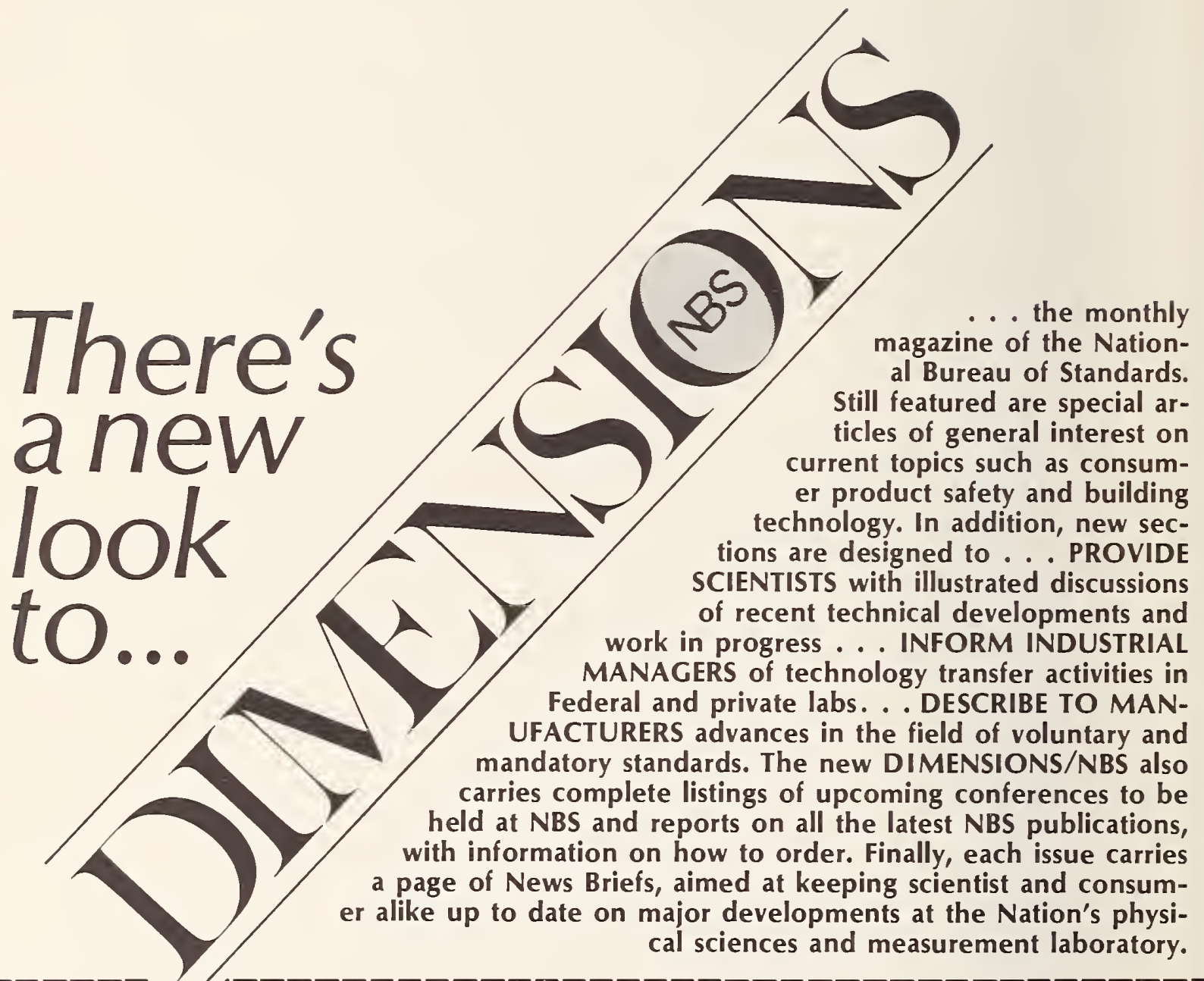

(please detach here)

\section{SUBSCRIPTION ORDER FORM}

Enter my Subscription To DIMENSIONS/NBS at $\$ 12.50$. Add $\$ 3.15$ for foreign mailing. No additional postage is required for mailing within the United States or its possessions. Domestic remittances should be made either by postal money order, express money order, or check. Foreign remittances should be made either by international money order, draft on an American bank, or by UNESCO coupons.

Send Subscription to:

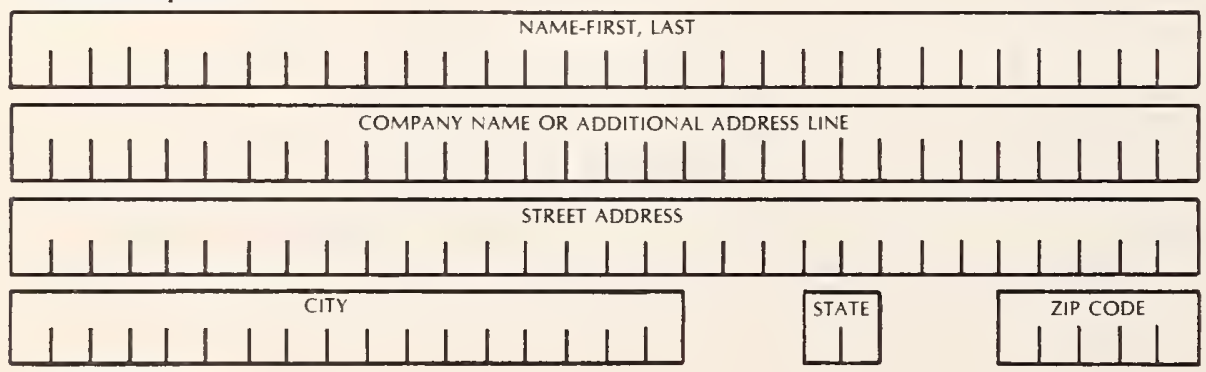

magazine of the Nation-

al Bureau of Standards.

Still featured are special aricles of general interest on current topics such as consumer product safety and building technology. In addition, new secSCIENTISTS with illustrated discussions of recent technical developments and work in progress ... INFORM INDUSTRIAL MANAGERS of technology transfer activities in Federal and private labs... DESCRIBE TO MANUFACTURERS advances in the field of voluntary and mandatory standards. The new DIMENSIONS/NBS also carries complete listings of upcoming conferences to be held at NBS and reports on all the latest NBS publications, with information on how to order. Finally, each issue carries cajor developments at the Nation's physi- 


\section{PERIODICALS}

JOURNAL OF RESEARCH-The Journal of Research of the National Bureau of Standards reports NBS research and development in those disciplines of the physical and engineering sciences in which the Bureau is active. These include physics, chemistry, engineering, mathematics, and computer sciences. Papers cover a broad range of subjects, with major emphasis on measurement methodology, and the basic technology underlying standardization. Also included from time to time are survey articles on topics closely related to the Bureau's technical and scientific programs. As a special service to subscribers each issue contains complete citations to all recent NBS publications in NBS and nonNBS media. Issued six times a year. Annual subscription: domestic $\$ 17.00$; foreign $\$ 21.25$. Single copy, $\$ 3.00$ domestic; $\$ 3.75$ foreign.

Note: The Journal was formerly published in two sections: Section A "Physics and Chemistry" and Section B "Mathematical Sciences."

\section{DIMENSIONS/NBS}

This monthly magazine is published to inform scientists, engineers, businessmen, industry, teachers, students, and consumers of the latest advances in science and technology, with primary emphasis on the work at NBS. The magazine highlights and reviews such issues as energy research, fire protection, building technology, metric conversion, pollution abatement, health and safety, and consumer product performance. In addition, it reports the results of Bureau programs in measurement standards and techniques, properties of matter and materials, engineering standards and services, instrumentation, and automatic data processing.

Annual subscription: Domestic, \$12.50; Foreign \$15.65.

\section{NONPERIODICALS}

Monographs-Major contributions to the technical literature on various subjects related to the Bureau's scientific and technical activities.

Handbooks-Recommended codes of engineering and industrial practice (including safety codes) developed in cooperation with interested industries, professional organizations, and regulatory bodies.

Special Publications-Include proceedings of conferences sponsored by NBS, NBS annual reports, and other special publications appropriate to this grouping such as wall charts, pocket cards, and bibliographies.

Applied Mathematics Series-Mathematical tables, manuals, and studies of special interest to physicists, engineers, chemists, biologists, mathematicians, computer programmers, and others engaged in scientific and technical work.

National Standard Reference Data Series-Provides quantitative data on the physical and chemical properties of materials, compiled from the world's literature and critically evaluated. Developed under a world-wide program coordinated by NBS. Program under authority of National Standard Data Act (Public Law 90-396).
NOTE: At present the principal publication outlet for these data is the Journal of Physical and Chemical Reference Data (JPCRD) published quarterly for NBS by the American Chemical Society (ACS) and the American Institute of Physics (AIP). Subscriptions, reprints, and supplements available from ACS, 1155 Sixteenth St. N.W., Wash., D.C. 20056.

Building Science Series-Disseminates technical information developed at the Bureau on building materials, components, systems, and whole structures. The series presents research results, test methods, and performance criteria related to the structural and environmental functions and the durability and safety characteristics of building elements and systems.

Technical Notes-Studies or reports which are complete in themselves but restrictive in their treatment of a subject. Analogous to monographs but not so comprehensive in scope or definitive in treatment of the subject area. Often serve as a vehicle for final reports of work performed at NBS under the sponsorship of other government agencies. Voluntary Product Standards-Developed under procedures published by the Department of Commerce in Part 10 , Title 15, of the Code of Federal Regulations. The purpose of the standards is to establish nationally recognized requirements for products, and to provide all concerned interests with a basis for common understanding of the characteristics of the products. NBS administers this program as a supplement to the activities of the private sector standardizing organizations.

Consumer Information Series-Practical information, based on NBS research and experience, covering areas of interest to the consumer. Easily understandable language and illustrations provide useful background knowledge for shopping in today's technological marketplace.

Order above NBS publications from: Superintendent of Documents, Government Printing Office, Washington, D.C. 20402.

Order following NBS publications-NBSIR's and FIPS from the National Technical Information Services, Springfield, Va. 22161 .

Federal Information Processing Standards Publications (FIPS PUB)-Publications in this series collectively constitute the Federal Information Processing Standards Register. Register serves as the official source of information in the Federal Government regarding standards issued by NBS pursuant to the Federal Property and Administrative Services Act of 1949 as amended, Public Law 89-306 (79 Stat. 1127), and as implemented by Executive Order 11717 (38 FR 12315, dated May 11, 1973) and Part 6 of Title 15 CFR (Code of Federal Regulations).

NBS Interagency Reports (NBSIR)-A special series of interim or final reports on work performed by NBS for outside sponsors (both government and non-government). In general, initial distribution is handled by the sponsor; public distribution is by the National Technical Information Services (Springfield, Va. 22161) in paper copy or microfiche form.

\section{BIBLIOGRAPHIC SUBSCRIPTION SERVICES}

The following current-awareness and literature-survey bibliographies are issued periodically by the Bureau:

Cryogenic Data Center Current Awareness Service. A literature survey issued biweekly. Annual subscription: Domestic, $\$ 25.00$; Foreign, $\$ 30.00$.

Liquified Natural Gas. A literature survey issued quarterly. Annual subscription: $\$ 20.00$.
Superconducting Devices and Materials. A literature survey issued quarterly. Annual subscription: $\$ 30.00$. Send subscription orders and remittances for the preceding bibliographic services to National Bureau of Standards, Cryogenic Data Center (275.02) Boulder, Colorado 80302. 
Washington, D.C. 20234

POSTAGE AND FEES PAIO U.S. OEPARTMENT OF COMMERCE

OFFICIAL BUSINESS

Penalty for Private Use. $\$ 300$

$$
\text { COM-2IS }
$$

SPECIAL FOURTH-CLASS RATE BOOK 